OAK RIDGE

NATIONAL LABORATORY

MANAGED BY UT-BATTELLE

FOR THE DEPARTMENT OF ENERGY

\title{
Results of the Indoor Radiological Survey of the Iowa Army Ammunition Plant, Middletown, Iowa
}

\author{
M. E. Murray \\ K. S. Brown \\ D. Bourne \\ R. E. Rodriguez \\ R. L. Coleman
}


ORNL/TM-2000/305

LIFE SCIENCES DIVISION

Results of the Indoor Radiological Survey of the Iowa Army Ammunition Plant, Middletown, Iowa

\author{
M. E. Murray \\ K. S. Brown \\ D. Bourne \\ R. E. Rodriguez \\ R. L. Coleman
}

July 2001

Investigation Team

R. D. Foley - Measurement Applications and Development Manager M. E. Murray - Survey Team Leader
K. J. Brown
R. L. Coleman
V. P. Patania
R. D. Foley
R. E. Rodriguez

Survey Team Members

Work performed by the MEASUREMENT APPLICATIONS AND DEVELOPMENT GROUP

Prepared by the OAK RIDGE NATIONAL LABORATORY

Oak Ridge, Tennessee 37831-6285 managed by

$$
\text { UT-BATTELLE, LLC, }
$$

for the

U. S. DEPARTMENT OF ENERGY

under contract DE-AC05-00OR22725 



\section{CONTENTS}

LIST OF FIGURES $\ldots \ldots \ldots \ldots \ldots \ldots \ldots \ldots \ldots \ldots \ldots \ldots \ldots \ldots$

LIST OF TABLES $\ldots \ldots \ldots \ldots \ldots \ldots \ldots \ldots \ldots \ldots \ldots \ldots \ldots \ldots, \ldots \ldots \ldots$

LIST OF ACRONYMS $\ldots \ldots \ldots \ldots \ldots \ldots \ldots \ldots \ldots \ldots \ldots \ldots \ldots \ldots \ldots \ldots$ vii

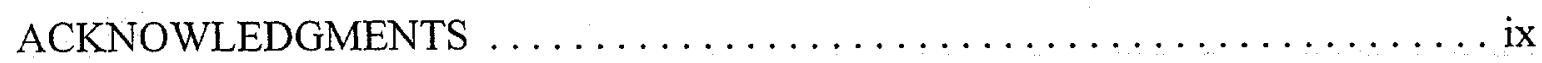

ABSTRACT $\ldots \ldots \ldots \ldots \ldots \ldots \ldots \ldots \ldots \ldots \ldots \ldots \ldots \ldots \ldots \ldots \ldots \ldots \ldots \ldots \ldots$

INTRODUCTION $\ldots \ldots \ldots \ldots \ldots \ldots \ldots \ldots \ldots \ldots \ldots \ldots \ldots \ldots \ldots \ldots \ldots \ldots$

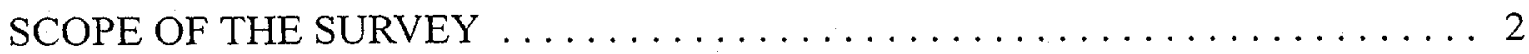

DATA QUALITY OBJECTIVES $\ldots \ldots \ldots \ldots \ldots \ldots \ldots \ldots \ldots \ldots \ldots \ldots \ldots \ldots \ldots \ldots$

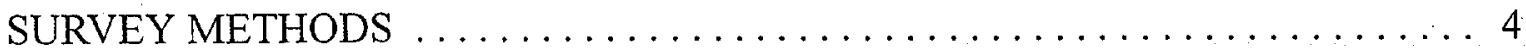

RADIATION MEASUREMENTS $\ldots \ldots \ldots \ldots \ldots \ldots \ldots \ldots \ldots \ldots \ldots \ldots$

SAMPLING AND ANALYSES $\ldots \ldots \ldots \ldots \ldots \ldots \ldots \ldots \ldots \ldots, 5$

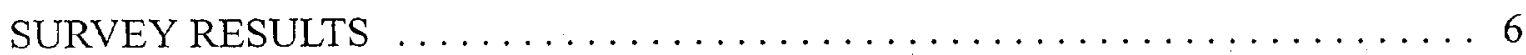

RADIATION MEASUREMENTS $\ldots \ldots \ldots \ldots \ldots \ldots \ldots \ldots \ldots \ldots$

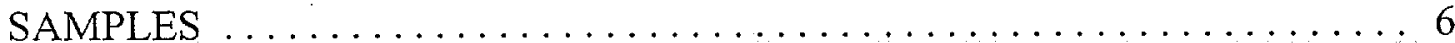

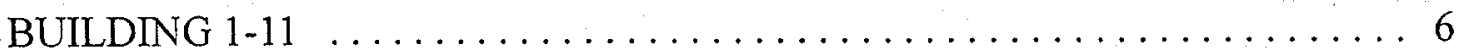

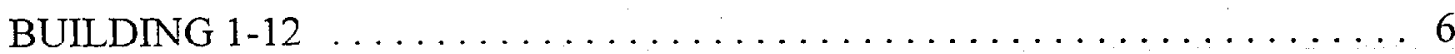

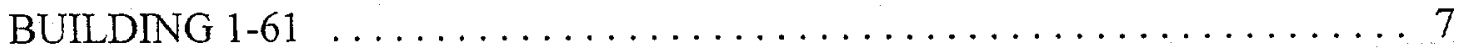

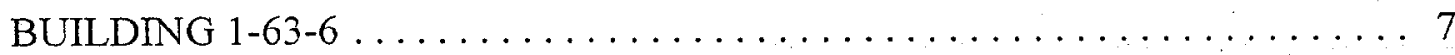

SIGNIFICANCE OF FINDINGS $\ldots \ldots \ldots \ldots \ldots \ldots \ldots \ldots \ldots \ldots \ldots$

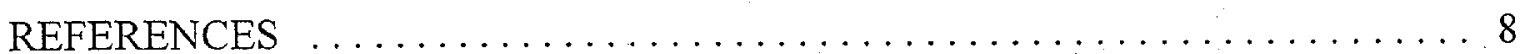





\section{LIST OF TABLES}

1 Surveyed IAAAP buildings $\ldots \ldots \ldots \ldots \ldots \ldots \ldots \ldots \ldots \ldots$

2 Directly measured radiation levels in buildings, Iowa Army Ammunition

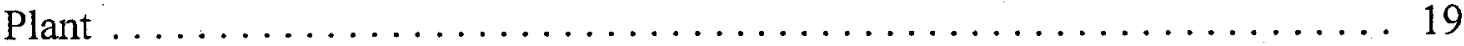

3 Smear data from buildings at Iowa Army Ammunition Plant $\ldots \ldots \ldots \ldots \ldots 24$

4. Summary of pressurized ionization chamber (PIC) measurements at the lowa

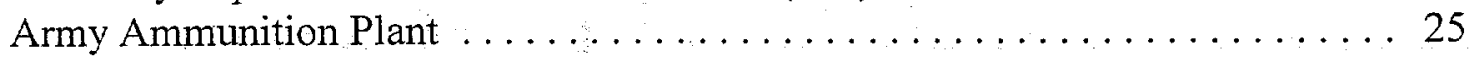

5 Air particulate sample data from buildings at Iowa Army Ammunition Plant . . . . . . . . . . . . . . . . . . . . . . 25

6 Concentrations of radionuclides in samples from Line 1, Iowa Army

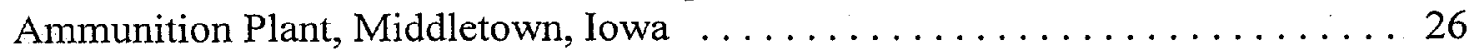

\section{LIST OF FIGURES}

1 Map of lowa showing the general location of the Iowa Army Ammunition Plant

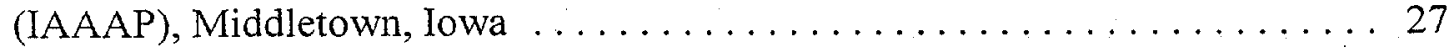

2 Map of IAAAP showing Line 1 and $\mathrm{C}$ Yard $\ldots \ldots \ldots \ldots \ldots \ldots \ldots \ldots \ldots \ldots \ldots$

3 Diagram showing surveyed buildings at Line 1 , IAAAP $\ldots \ldots \ldots \ldots \ldots 29$

4 Diagram of Building 1-11 showing results of radiation survey and a view of

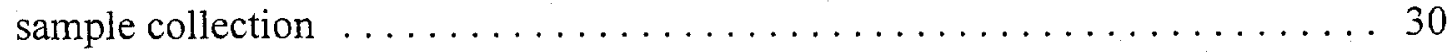

5 Diagram of Building 1-63-6 showing results of radiation survey and views of return air filters and sample collection . . . . . . . . . . . . . . . 31

6 Diagram of Building 1-12 showing results of radiation survey $\ldots \ldots \ldots \ldots 32$ 



\section{LIST OF ACRONYMS}

$\begin{array}{ll}\text { AEC } & \text { Atomic Energy Commission } \\ \text { CERCLA } & \text { Comprehensive Environmental Response, Compensation and Liability Act } \\ \text { CPM } & \text { counts per minute } \\ \text { DCGL } & \text { derived concentration guideline } \\ \text { DOE } & \text { Department of Energy } \\ \text { dpm } & \text { disintegrations per minute } \\ \text { DQO } & \text { data quality objective } \\ \text { DU } & \text { depleted uranium } \\ \text { EPA } & \text { Environmental Protection Agency } \\ \text { FIDLER } & \text { field instrument for detection of low-energy radiation } \\ \text { FS } & \text { firing site } \\ \text { GM } & \text { Geiger-Mueller } \\ \text { h } & \text { hour } \\ \text { IAAAP } & \text { Iowa Army Ammunition Plant } \\ \text { L/min } & \text { liters/minute } \\ \text { LAP } & \text { load, assemble and pack } \\ M A R S S I M & \text { Multi-Agency Radiation Survey and Site Investigation Manual } \\ \text { MDA } & \text { minimum detectable activity } \\ \mu R / h & \text { microroentgen per hour } \\ \text { NaI } & \text { sodium iodide } \\ \text { NaI(TI) } & \text { thallium-activated sodium iodide crystal } \\ \text { ND } & \text { not detected } \\ \text { ORNL } & \text { Oak Ridge National Laboratory } \\ \text { PIC } & \text { pressurized ionization chamber } \\ \text { ROD } & \text { Record of Decision } \\ \text { SARA } & \text { Superfund Amendments and Reauthorization Act } \\ \text { ZnS } & \text { zinc sulfide } \\ \end{array}$




\section{ACKNOWLEDGMENTS}

This project was sponsored by the U.S. Department of Energy (DOE) under contract DE-AC05-00OR22725 with UT-Battelle, LLC. The authors wish to acknowledge the guidance and assistance of George Rael of the DOE Albuquerque Operations Office and Amina Khan of DOE Headquarters.

LTC Bruce Elliott and CPT George Davis of the U. S. Army at IAAAP were very helpful in support of the survey. The logistics and field support of Robert Haines at IAAAP was instrumental in making the survey proceed in an efficient manner. 



\begin{abstract}
At the request of the U.S. Department of Energy (DOE), a team from Oak Ridge National Laboratory conducted an indoor radiological survey of property at the Iowa Army Ammunition Plant (IAAAP), Middletown, lowa in June 2000. The purpose of the survey was to determine if radioactive residuals resulting from previous Atomic Energy Commission (AEC) activities were present inside selected Line 1 buildings at the IAAAP and conduct sampling in those areas of previous AEC operations that utilized radioactive components at some point during the manufacturing process, in order to evaluate any possible immediate health hazards and to collect sufficient information to determine the next type of survey. The AEC occupied portions of IAAAP from 1947 to 1975 to assemble nuclear weapons. The surveyed areas were identified through interviews with current and former IAAAP employees who had worked at the plant during AEC's tenure, and from AEC records.
\end{abstract}

The Secretary of Energy committed to perform a radiological survey of Line 1 and Firing Site 12 (FS-12) in response to questions and concerns raised by private citizens in a public forum held in Burlington, lowa. The questions and concerns related to any immediate threat of public harm resulting from AEC operations at these areas of IAAAP. The Indoor Radiological Survey was performed to partially fulfill the Secretary's commitment made on January 6, 2000. The initial scope of the radiological survey consisted of two phases; the indoor survey of selected buildings at Line 1 and $C$ Yard and, shortly thereafter, the outdoor survey of Line 1 and FS-12. ORNL planned to use information from the indoor survey to show the status indoors as well as to provide insight into transport of contamination to the environment. During the time the survey team spent at IAAAP conducting the indoor survey, the survey team also collected other information to plan the outdoor phase. It was intended that the results of both phases would be combined to provide a comprehensive assessment report on the areas surveyed. However, since this approach was planned, the Formerly Utilized Sites Remedial Action Program (FUSRAP) has, in response to DOE's request, assumed responsibility for former AEC areas at IAAAP. As a result, subsequent surveys will be conducted by FUSRAP.

The indoor survey included a walkover gamma scan, surface alpha/beta scan, fixed-point measurements and exposure rate measurements in designated areas inside selected buildings, and the collection of systematic air samples, in addition to biased debris and smear samples. On-site and subsequent radionuclide analyses were performed on samples. Residual radioactive materials, determined by gamma spectroscopy to be depleted uranium, were found in Buildings 1-11, 1-63-6, $1-12$, and 1-61.

Based on historical records and site conditions, the contamination in Building 1-11 is likely results of $\mathrm{AEC}$ activities. $\mathrm{AEC}$ used the building for shipping and receiving and the location and nature of the contamination found is consistent with AEC activities. Because of the relative newness of the return air filters and radiation protection signs, contamination in building 1-63-6 is most likely due to Army operation at IAAAP. Similarly, the contaminated plastic storage pan found in 1-61 was relatively new, which indicates that the contamination was likely due to Army operations. As both AEC and the Army have conducted operations in Building 1-12, the origin of the contamination found there can not be ascertained with the information currently available. 


\section{Results of the Indoor Radiological Survey of the Iowa Army Ammunition Plant, Middletown, Iowa*}

\section{INTRODUCTION}

Iowa Army Ammunition Plant (IAAAP) is a government facility, owned by the United States Army and operated by a private contractor, American Ordnance Co. It is located in the southeastern part of lowa, near the town of Middletown, Des Moines County, approximately 10 miles west of the Mississippi River. The IAAAP is a secured facility covering 19,127 acres in a rural setting. Approximately 7,751 acres are leased for agricultural use, 7,500 acres are forested land, and the remaining area is used for administrative and industrial operations.

IAAAP was initially developed in 1941 , and it has undergone modernization and expansion since then. Production of supplies for World War II at the facility began in September 1941 and ended in August 1945. Production was resumed in 1949 and has continued to the present. In the 1960s and early 1970s, the IAAAP produced supplies for wars in southeast Asia. During peacetime, activities at the plant continue at a reduced level. Also, from 1946 to 1950 , nitrogen fertilizer was produced at Line 8. From about 1947 to 1975, the former Atomic Energy Commission (AEC) operated facilities on the site, which then reverted to Army control in $1975 .{ }^{1}$

IAAAP is currently operating to load, assemble, and pack (LAP) anmunition items, including projectiles, mortar rounds, warheads, demolition charges; anti-tank mines, antipersonnel mines, and the components of these munitions, including primers, detonators, fuses, and boosters. The LAP operations use explosive material and lead-based initiating compounds. Only a few of the production lines are currently in operation.

The AEC operated a portion of Line 1 for several years beginning in 1947. Due to the nature of the AEC operations, less information is available on the activities conducted during AEC's work at Line 1. However, it is known that various components were assembled into a finished nuclear weapon. Radioactive materials used at the line were "received in a sealed configuration" and were swipe tested for leaks before use. Known radioactive materials include depleted uranium (DU), enriched uranium, plutonium, tritium gas, and polonium-210. The AEC announced in 1973 that it was phasing out use of the plant. These facilities reverted back to Army control 1 July $1975 .{ }^{1}$

The firing site area is located in the western portion of the IAAAP and has been in use since the 1940s. Firing Site 12 (FS-12), which is located at the northern end of the firing

*The survey was performed by members of the Measurement Applications and Development Group and the Health Effects Group of the Life Sciences Division at Oak Ridge National Laboratory under DOE contract DE-AC05-00OR22725. 
site area, was used for AEC activities. Between 1965 and 1973 FS-12 was used for the destructive testing of 701 shots of DU and high explosives.

Prior to its departure, AEC conducted a radiological survey of the areas it occupied and detcrmined that the only real property which contained residual radioactive contamination was FS-12. Contaminated soil at FS-12 was excavated and transported to a waste disposal facility in Sheffield, Illinois.

The U.S. Environmental Protection Agency (EPA) added IAAAP to the National Priorities List in 1990. The Army, as an agency within the DOD, is the lead agency for implementing the interim remedial action at IAAAP. 'As the support agency, EPA oversees cleanup activities conducted by the Army to ensure that requirements of the Comprehensive Environmental Response, Compensation and Liability Act (CERCLA), the Superfund Amendments and Reauthorization Act (SARA), and the National Contingency Plan have been met. The EPA and the Army signed a Federal Facilities Agreement for site cleanup, which became effective December 10, 1990. ${ }^{2}$

Numerous investigations have been conducted at the site by the Army from 1975 to the present to investigate soil and groundwater contamination. Based on data collected from the site, the Army has initiated response actions to address soil contamination at several areas across the IAAAP. An IAAAP Restoration Advisory Board (RAB) has been established to enable the community and government representatives to meet and exchange information. A Record of Decision (ROD) has been issued for Soils Operable Unit \#1, and remediation is ongoing. Separate RODs will be issued for groundwater and installationwide issues. ${ }^{2}$

In June 2000 , a radiological survey was conducted at IAAAP by personnel from ORNL at the request of DOE. The Secretary of Energy committed to perform a radiological survey of areas used by the AEC in response to questions and concerns raised by private citizens in a public forum held in Burlington, Iowa. The questions and concerns related to any immediate threat of public harm resulting from AEC operations at these areas of the IAAAP. This radiological scoping survey of Line 1 and $C$ Yard indoors was performed to partially fulfill the Secretary's commitment made on January 6,2000. Results of that survey are presented in this report. The general location of the IAAAP is shown in Fig. 1. The general layout of IAAAP including Line 1, the FS Area and C Yard are shown in Fig. 2.

\section{SCOPE OF THE SURVEY}

The indoor radiological scoping survey of June 2000 included a surface beta-gamma scan of accessible areas inside selected Line 1 and C Yard buildings, a scan of greater than $80 \%$ of floor surfaces with a floor monitor probe, a scan of less accessible areas with a beta/gamma pancake probe, and direct measurement of gamma, alpha, and beta-gamma radiation levels inside the surveyed buildings. About $1 \%$ of the wall surfaces in each room were scanned for both alpha and beta-gamma radiation using portable instrumentation 
where areas of floor contamination were found. A small percentage of the overhead structures was also surveyed for both alpha and beta-gamma radiation, depending upon how much contamination was detected in floor areas. Measurements were also made on miscellaneous structures, including air ventilation systems, floor drains, equipment and window sills. Special attention was given to areas where contamination typically collects; i.e., cracks, joints, and corners. Surveyed buildings are listed in Table 1 and shown on Figure 3.

Systematic air samples, in addition to biásed debris and smear samples, were collected from some buildings for radionuclide analysis. Systematic samples were collected without regard to radiation level; biased samples were collected at locations of elevated beta-gamma levels. A sampling and analysis plan was approved prior to the survey which detailed the data quality objectives (DQOs) and survey details.

\section{DATA QUALITY OBJECTIVES}

The two main objectives of this scoping survey were to 1) collect data to evaluate any possible immediate health hazards, and 2) conduct radiological measurements to plan "Final Status Surveys" and/or "Characterization Surveys" consistent with the Multi-Agency Radiation Survey and Site Investigation Manual (MARSSIM). ${ }^{3}$

This scoping survey activity provides input for additional characterization, including a limited amount of surface scanning, surface activity measurements, and sample collection (smears, air samples, building materials, debris). In this case, scans, direct measurements, and samples were used to examine areas likely to contain residual radioactive material. These activities were conducted based on historic site data, preliminary investigation surveys, and professional judgment.

Background activity and radiation levels for the area were determined, including direct radiation levels on building surfaces and radionuclide concentrations in media. Survey locations were referenced to fixed site features. Samples collected as part of this scoping survey were tracked as part of the chain of custody.

The two DQOs included the following actions:

1. Collection of data to evaluate immediate radiological health hazards by:

- Collection of air particulate samples;

- Direct radiation exposure measurements;

- Determining transferrable contamination;

- Determining possible release and migration pathways to plan an outside survey; and

- Data from 2. below. 
2. Conducting radiological measurements to plan "Final Status Surveys" and/or "Characterization Surveys" by:

- using portable radiation survey instrumentation to locate alpha, beta, and gamma emitting nuclides in suspect areas of the buildings. The purpose was to identify any areas where residual contamination exists.

- investigating suspect areas identified from scans to identify the isotopes and magnitudes; activity per unit area and area size using portable instruments and samples.

- evaluating survey data and recommending area classifications as

1. No radiation detected above background, ready for final status survey; or

2. Contaminated above background, needs further characterization.

The above DQOs were accomplished assuming:

- The likely contaminants of concern were isotopes of uranium and plutonium and that they would tend to be found in the same locations if present. Isotopes of lesser concern were tritium, cobalt-60, radium-226, polonium-210, and cesium-137. These isotopes would be found, if present, during the survey for the primary contaminants, with the exception of tritium and polonium-210. Surveying for tritium was not considered practical because only gaseous tritium should have been present, and it would have most likely dissipated since the last recorded release. The Po-210 was used as part of a neutron generator, has a 138-day half-life, and therefore could not still be detected.

- Estimated derived concentration guidelines (DCGLs) used in the survey were only for the purpose of designing the survey, selecting the appropriate instruments, and evaluating scan rates and minimum detectable activities (MDAs). These DCGLs were not considered to be approved for determining if the building may be released for unrestricted use.

\section{SURVEY METHODS}

A comprehensive description of the methods and instrumentation used in this survey and in the laboratory analyses is given in Measurement Applications and Development Group Guidelines, ORNL-6782 (January 1995). ${ }^{4}$ General guidance for scoping surveys, instrumentation, DQOs, and data evaluation is given in MARSSIM.

Drawings were prepared for buildings using the IAAAP grid coordinates. Survey and sample locations were designated by reference to fixed site features. 


\section{RADIATION MEASUREMENTS}

Gamma radiation levels were determined using portable $\mathrm{NaI}$ gamma scintillation meters. Because NaI gamma scintillators are energy dependent, measurements of gamma radiation levels in counts per minute are normalized to pressurized ionization chamber (PIC) measurements to estimate gamma exposure rates in $\mu \mathrm{R} / \mathrm{h}$. Direct exposure measurements were also taken with a PIC in selected buildings and recorded in $\mu \mathrm{R} / \mathrm{h}$.

The FIDLER connected to Ludlum 2221 scaler/ratemeters was used to measure the relative gamma fluence at the interior floor surface with the purpose of detecting gammaemitting radionuclide contamination beneath floor surfaces. The FIDLER is a NaI(Tl) scintillation probe that is designed to be particularly sensitive to low-energy gamma and $x$-ray radiation. The sensitive volume is 5 inches in diameter by 0.0063 inches thick, and the instrument is preferentially efficient at measuring gamma fluence rates entering perpendicular to the entrance window. Systematic measurements in counts per minute were taken.

Bicron scaler/ratemeters with Geiger-Mueller (GM) pancake detectors were used to detect beta-gamma radiation. Radiation levels in counts per minute ( $\mathrm{cpm}$ ) were converted to disintegrations per minute $(\mathrm{dpm})$ per $100 \mathrm{~cm}^{2}$.

Floors were surveyed with the Ludlum Model 239-1F gas flow proportional detector system ("floor monitor"), which includes a Ludlum Model 2221 scaler/ratemeter connected to a Ludlum Model 43-37 detector probe mounted on a roll-around cart. The monitor was set in the "beta" mode, where it is primarily used to detect beta radiation but will detect alpha particles.

Alpha levels on selected surfaces were measured with an ORNL $100 \mathrm{~cm}^{2} \mathrm{ZnS}$ alpha scintillator probe connected to a Bicron Analyst scaler/ratemeter. Air samples were collected using a portable constant flow air sampler (RADeCO AVS-28A).

\section{SAMPLING AND ANALYSES}

Systematic air particulate samples, systematic and biased smear samples, and biased debris samples were collected from six buildings for radionuclide analysis. Biased samples were collected in areas exhibiting an anomaly as determined by field instrument measurements, and were analyzed by gamma spectroscopy. Sampling locations for Building 1-11 and Building 1-63-6 are shown on Figs. 4 and 5, respectively. Buildings where air samples were collected are designated on Table 1. 


\section{SURVEY RESULTS}

\section{RADIATION MEASUREMENTS}

Directly measured alpha and beta-gamma radiation levels in each building are listed in Table 2. Typical background radiation levels were determined for the surveyed buildings by using survey data from buildings where contamination was not expected and not found. Smear data from selected buildings is summarized in Table 3. Gamma exposure rates inside the buildings on the property generally ranged from 6 to $14 \mu \mathrm{R} / \mathrm{h}$. Gamma ranges are shown in Table 1 for buildings where values were higher than background. A summary of PIC measurements is shown in Table 4. The scan of interior areas with a floor monitor probe and beta/gamma pancake probe showed no elevated radiation levels above background levels, with the exception of areas where biased samples were collected.

\section{SAMPLES}

Results of analyses of air samples are shown in Table 5. Miscellaneous sample locations for Buildings 1-11, 1-12 and 1-63-6 only are shown on Figs. 4-6, and results of analyses are listed in Table 6.

\section{BUILDING 1-11}

The contamination found in Building 1-11 is primarily limited to the northwest corner of the building. One small spot of contamination was found near the south loading dock. Fig. 4 illustrates areas of contamination. As expected, the highest residual contamination was found in the cracks and concrete seams. Samples M1 and M8 were analyzed by gamma spectroscopy to determine the contaminant to be DU. Smear samples T1, T2, and T3 indicated that the contamination is not transferrable under normal use. Soil sample S1 was collected outside the exit door in the northwest corner and contained only DU and a trace amount of cesium-137 consistent with fallout from aboveground weapons tests.

Also within the northwest corner of 1-11 is a pit containing about 18 inches of water and covered with a metal grate. Portions of the grate showed contamination up to 31,000 $\mathrm{dpm} / 100 \mathrm{~cm}^{2}$. The gamma exposure rates in the area were not distinguishable from

background. Radiological survey results from the 1970s indicated radioactive materials were handled in this area.

\section{BUILDING 1-12}

The areas surveyed in Building 1-12 were the bays designated with double letters (AA through FF). The contamination found was limited to the concrete seam in Bay CC. The maximum measurement was $13,000 \mathrm{dpm} / 100 \mathrm{~cm}^{2}$ beta. Analysis of sample M9 by gamma spectroscopy indicated the contamination to be DU. Figure 6 illustrates areas of contamination. 


\section{BUILDING 1-61}

The contamination found in Building 1-61 was inside a plastic storage pan located in Bay R. The contamination was identified by gamma spectroscopy as DU and was readily transferrable. Smear sample T4 was removed from the pan, and analysis showed 2500 $\mathrm{dpm} / 100 \mathrm{~cm}^{2}$. Direct measurements were as high as $1000 \mathrm{dpm} / 100 \mathrm{~cm}^{2}$ alpha and 30,000 $\mathrm{dpm} / 100 \mathrm{~cm}^{2}$ beta. The plastic pan was tagged as contaminated and reported to the IAAAP staff. The pan was subsequently removed from 1-61.

\section{BUILDING 1-63-6}

Contamination was found in four locations. It should be noted that just inside the entrance to 1-63-6 is a "Caution Radiation" sign indicating recent work with radioactive materials. Figure 5 details the layout of 1-63-6, the measurements and sample locations. All of the contamination found was identified by gamma spectroscopy as DU. A small spot $\left(<50 \mathrm{~cm}^{2}\right)$ of loose contamination was found near the entrance; however, smear sample T5 indicated the material was not readily picked up by conventional smear sampling. Sample M2 collected from the debris was analyzed and found to have $39,000 \mathrm{pCi} / \mathrm{g}$ DU. Direct measurements revealed $150,000 \mathrm{dpm} / 100 \mathrm{~cm}^{2}$ beta, $290 \mathrm{dpm} / 100 \mathrm{~cm}^{2}$ alpha, and $14 \mu \mathrm{R} / \mathrm{h}$ gamma at the spot.

Samples were taken from a sump (M5) and floor drain (M6). Sample analysis showed $2.3 \mathrm{pCi} / \mathrm{g}$ and $86 \mathrm{pCi} / \mathrm{g}$ DU, respectively. The most significant contamination found was on the return air filters in the round process area of 1-63-6. Twelve 24 " x 24 " filters were mounted in a metal support housing. The filters were generally contaminated at levels of 20,000 to $30,000 \mathrm{dpm} / 100 \mathrm{~cm}^{2}$ beta-gamma. Given the poor measurement geometry, the likely radioactivity is reasonably higher. Measurements inside the ductwork and downstream filters showed no additional contamination. A portion of one of the filters was collected as sample M7, and analysis of the sample by gamma spectroscopy showed 2600 $\mathrm{pCi} / \mathrm{g}$ of DU.

\section{SIGNIFICANCE OF FINDINGS}

The indoor radiological survey was conducted at the request of the DOE to document the radiological status of the designated areas of the IAAAP, Middletown, Iowa. No immediate threat to human health was discovered during the survey.

Residual radioactive materials, determined to be DU, were found in Buildings 1-11, $1-63-6,1-12$, and 1-61. The areas identified as containing residual radioactive materials should be marked as such according to applicable regulations. Additional characterization (according to MARSSIM) is required, and remediation may be necessary. 
Based on historical records and site conditions, the contamination in Building 1-11 is likely the result of AEC activities. AEC used the building for shipping and receiving and the location and nature of the contamination found is consistent with AEC activities. Because of the relative newness of the return air filters and radiation protection signs, contamination in building 1-63-6 is most likely due to Army operation at IAAAP. Similarly, the contaminated plastic storage pan found in 1-61 was relatively new, which indicates that the contamination was likely due to Army operations. As both AEC and the Army have conducted operations in Building 1-12, the origin of the contamination found there can not be ascertained with the information currently available.

Except for the aforementioned, all the other buildings surveyed at Line 1 and $\mathrm{C}$ Yard may be classified as Class 3 according to MARSSIM and ready for final status survey. Unless otherwise suspected, the contaminant of concern is DU.

\section{REFERENCES}

1. Remedial Investigation/Risk Assessment, lowa Army Ammunition Plant, Middletown, lowa. Revised draft final, May 1996. U.S. Army Environmental Center, Aberdeen Proving Ground, Maryland.

2. Record of Decision, Iowa Army Ammunition Plant Soils Operable Unit \#1, Middletown, Iowa. Revision No. 1, August 14, 1998. Department of the Army, Corps of Engineers, Omaha District, Omaha, Nebraska.

3. Multi-Agency Radiation Survey and Site Investigation Manual (MARSSIM). NUREG1575/EPA 402-R-97-016. December 1997. Department of Defense, Department of Encrgy, Environmental Protection Agency, Nuclear Regulatory Commission.

4. Measurement Applications and Development Group Guidelines, ORNL-6782, Martin Marietta Energy Systems, Inc., Oak Ridge National Laboratory, January 1995. 


\begin{tabular}{|c|c|c|}
\hline \multicolumn{3}{|c|}{ Table 1. Surveyed IAAAP buildings } \\
\hline Building Number ${ }^{a}$ & $\begin{array}{l}\text { Building } \\
\text { Description }\end{array}$ & Comments $^{b}$ \\
\hline $1-11^{c, d}$ & Shipping/Receiving & $\begin{array}{l}\text { General coverage with floor monitor and NaI gamma detector. Static } \\
\text { measurements with GM pancake beta-gamma detector and } \mathrm{ZnS} \text { alpha meter: } \\
\text { Random and biased measurements with } \mathrm{GM} \text { pancake and } \mathrm{ZnS} \text { alpha meter. } \\
\text { Floor monitor coverage: Perimeter, all seams and cracks, meandering of } \\
\text { remainder, spccial attcntion to scored areas, chips, etc. Beta-gamma scan of } \\
\text { rail tracks outside NE entrance. Soil sample S1 taken outside NW corner of } \\
\text { building. } \\
\text { Bay 1: } ~ 500 \mathrm{ft}^{2} \text { of NW corner around pit generally contaminated. Some } \\
\text { concrete low-level contaminated. Seven (out of many) spots characterized. } \\
\text { Highest spot } \sim 31,000 \mathrm{dpm} / 100 \mathrm{~cm}^{2} \text { beta. Low alpha, }<60 \mathrm{dpm} / 100 \mathrm{~cm}^{2} \text {. } \\
\text { Generally contaminated in seams and on steel grate above pit. Samples } \mathrm{T} 1 \text {, } \\
\text { M8 taken from crack. Sample T2 taken from concrete seam. Approx. } 18^{\prime \prime} \text { of } \\
\text { water in pit - inaccessible. Sample T3 taken from steel grate above pit. } \\
\text { Another spot }-31,000 \mathrm{dpm} / 100 \mathrm{~cm}^{2} \text { beta found in concrete seam near } \\
\text { loading dock on south side of } 1-11 \text {. Sample } \mathrm{Ml} \text { taken here. }\end{array}$ \\
\hline $\begin{array}{l}1-12(\mathrm{AA}, \mathrm{BB}, \mathrm{CC} \\
\mathrm{DD}, \mathrm{EE}, \mathrm{FF})\end{array}$ & Painting & $\begin{array}{l}\text { General coverage with floor monitor and } \mathrm{NaI} \text { gamma detector. Static } \\
\text { measurements with GM pancake beta-gamma detector and } \mathrm{ZnS} \text { alpha meter } \\
\text { Random and biased measurements with GM pancake and } \mathrm{ZnS} \text { alpha meter. } \\
\text { Gamma } 7-10 \mu \mathrm{R} / \mathrm{h} \text {. } \\
\text { Bay CC: Crack running } \mathrm{E} / \mathrm{W} \text { in center of room generally contaminated } \\
\text { throughout; } 670-13,000 \mathrm{dpm} / 100 \mathrm{~cm}^{2} \text { beta with } \mathrm{GM} \text { pancake. No alpha or } \\
\text { gamma detected above background. Samples } \mathrm{M} 9 \text { and T6. }\end{array}$ \\
\hline $\begin{array}{l}1-13(A, B, C, D, E, F \text {, } \\
G)\end{array}$ & Development & $\begin{array}{l}\text { General coverage with floor monitor and } \mathrm{NaI} \text { gamma detector. Static } \\
\text { measurements with GM pancake beta-gamma detector and } \mathrm{ZnS} \text { alpha meter } \\
\text { Random and biased measurements with GM pancake and } \mathrm{ZnS} \text { alpha meter. } \\
\text { No anomalies. Gamma } 7-13 \mu \mathrm{R} / \mathrm{h} \text {. }\end{array}$ \\
\hline
\end{tabular}


Table 1 (continued)

\begin{tabular}{|c|c|c|}
\hline Building Number" & $\begin{array}{l}\text { Building } \\
\text { Description }\end{array}$ & Comments $^{b}$ \\
\hline $1-18$ & Development & $\begin{array}{l}\text { General coverage with floor monitor and NaI gamma detector. Static } \\
\text { measurements with GM pancake beta-gamma detector and } \mathrm{ZnS} \text { alpha meter } \\
\text { Random and biased measurements with GM pancake and } \mathrm{ZnS} \text { alpha meter: } \\
\text { No anomalies. Gamma } 7-11 \mu \mathrm{R} / \mathrm{h} \text {. }\end{array}$ \\
\hline $1-19-1$ & Development & $\begin{array}{l}\text { General coverage with floor monitor and } \mathrm{NaI} \text { gamma detector. Static } \\
\text { measurements with GM pancake beta-gamma detector and } \mathrm{ZnS} \text { alpha meter } \\
\text { Random and biased measurements with GM pancake and } \mathrm{ZnS} \text { alpha meter. } \\
\text { No anomalies. Gamma } 7 \mu \mathrm{R} / \mathrm{h} \text {. }\end{array}$ \\
\hline $1-19-2$ & Development & $\begin{array}{l}\text { General coverage with floor monitor and } \mathrm{NaI} \text { gamma detector. Static } \\
\text { measurements with GM pancake beta-gamma detector and } \mathrm{ZnS} \text { alpha meter. } \\
\text { Random and biased measurements with GM pancake and } \mathrm{ZnS} \text { alpha meter. } \\
\text { No anomalies. Gamma } 7 \mu \mathrm{R} / \mathrm{h} \text {. }\end{array}$ \\
\hline $1-19-3^{c}$ & Development & $\begin{array}{l}\text { General coverage with floor monitor and NaI gamma detector. Static } \\
\text { measurements with GM pancake beta-gamma detector and } \mathrm{ZnS} \text { alpha meter } \\
\text { Random and biased measurements with GM pancake and } \mathrm{ZnS} \text { alpha meter. } \\
\text { No anomalies. Gamma } 7 \mu \mathrm{R} / \mathrm{h} \text {. }\end{array}$ \\
\hline $1-19-4$ & Development & $\begin{array}{l}\text { General coverage with floor monitor and NaI gamma detector. Static } \\
\text { measurements with GM pancake beta-gamma detector and } \mathrm{ZnS} \text { alpha meter } \\
\text { Random and biased measurements with GM pancake and } \mathrm{ZnS} \text { alpha meter. } \\
\text { No anomalies. Gamma } 7 \mu \mathrm{R} / \mathrm{h} \text {. }\end{array}$ \\
\hline $1-19-5$ & Development & $\begin{array}{l}\text { General coverage with floor monitor and } \mathrm{NaI} \text { gamma detector. Static } \\
\text { measurements with GM pancake beta-gamma detector and } \mathrm{ZnS} \text { alpha meter } \\
\text { Random and biased measurements with GM pancake and } \mathrm{ZnS} \text { alpha meter. } \\
\text { No anomalies. Gamma } 5 \mu \mathrm{R} / \mathrm{h} \text {. }\end{array}$ \\
\hline
\end{tabular}


Table 1 (continued)

\begin{tabular}{|c|c|c|}
\hline Building Number" & $\begin{array}{l}\text { Building } \\
\text { Description }\end{array}$ & Comments $^{b}$ \\
\hline $1-19-6$ & Development & $\begin{array}{l}\text { General coverage with floor monitor and } \mathrm{NaI} \text { gamma detector: Static } \\
\text { measurements with GM pancake beta-gamma detector and } \mathrm{ZnS} \text { alpha meter: } \\
\text { Random and biased measurements with GM pancake and } \mathrm{ZnS} \text { alpha meter. } \\
\text { No anomalies. Gamma } 6 \mu \mathrm{R} / \mathrm{h} \text {. }\end{array}$ \\
\hline $1-19-7$ & Development & $\begin{array}{l}\text { General coverage with floor monitor and } \mathrm{NaI} \text { gamma detector: Static } \\
\text { measurements with GM pancake beta-gamma detector and } \mathrm{ZnS} \text { alpha meter } \\
\text { Random and biased measurements with } \mathrm{GM} \text { pancake and } \mathrm{ZnS} \text { alpha meter. } \\
\text { No anomalies. Gamma } 6 \mu \mathrm{R} / \mathrm{h} \text {. }\end{array}$ \\
\hline $1-10\left(G^{c}, H, J, Q, S\right)$ & Machining & $\begin{array}{l}\text { General coverage with floor monitor and } \mathrm{NaI} \text { gamma detector: Static } \\
\text { measurements with GM pancake beta-gamma detector and } \mathrm{ZnS} \text { alpha meter. } \\
\text { Random and biased measurements with GM pancake and } \mathrm{ZnS} \text { alpha meter. } \\
\text { No anomalies. }\end{array}$ \\
\hline $1-61^{d}$ & Assembly & 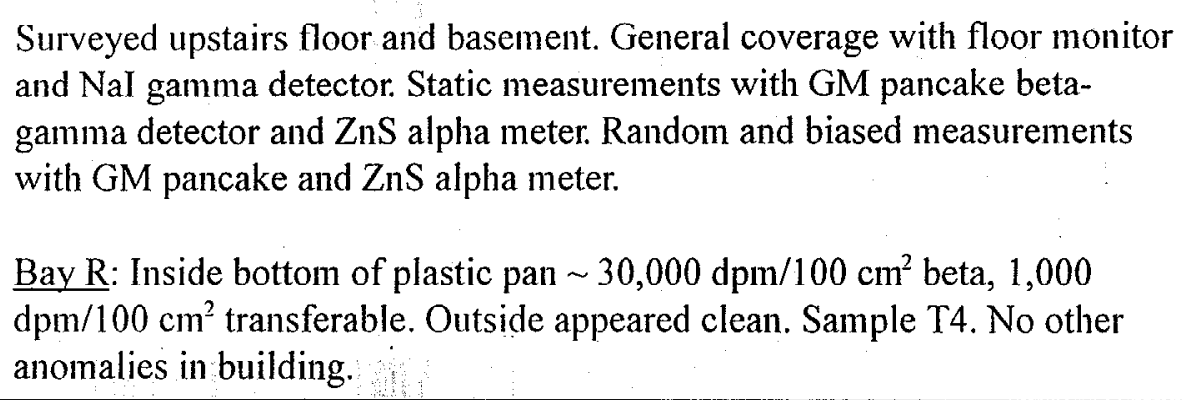 \\
\hline $1-63-1$ & Assembly & $\begin{array}{l}\text { General coverage with floor monitor and } \mathrm{NaI} \text { gamma detector. Static } \\
\text { measurements with GM pancake beta-gamma detector and } \mathrm{ZnS} \text { alpha meter } \\
\text { Random and biased measurements with GM pancake and } \mathrm{ZnS} \text { alpha meter. } \\
\text { No anomalies. }\end{array}$ \\
\hline
\end{tabular}




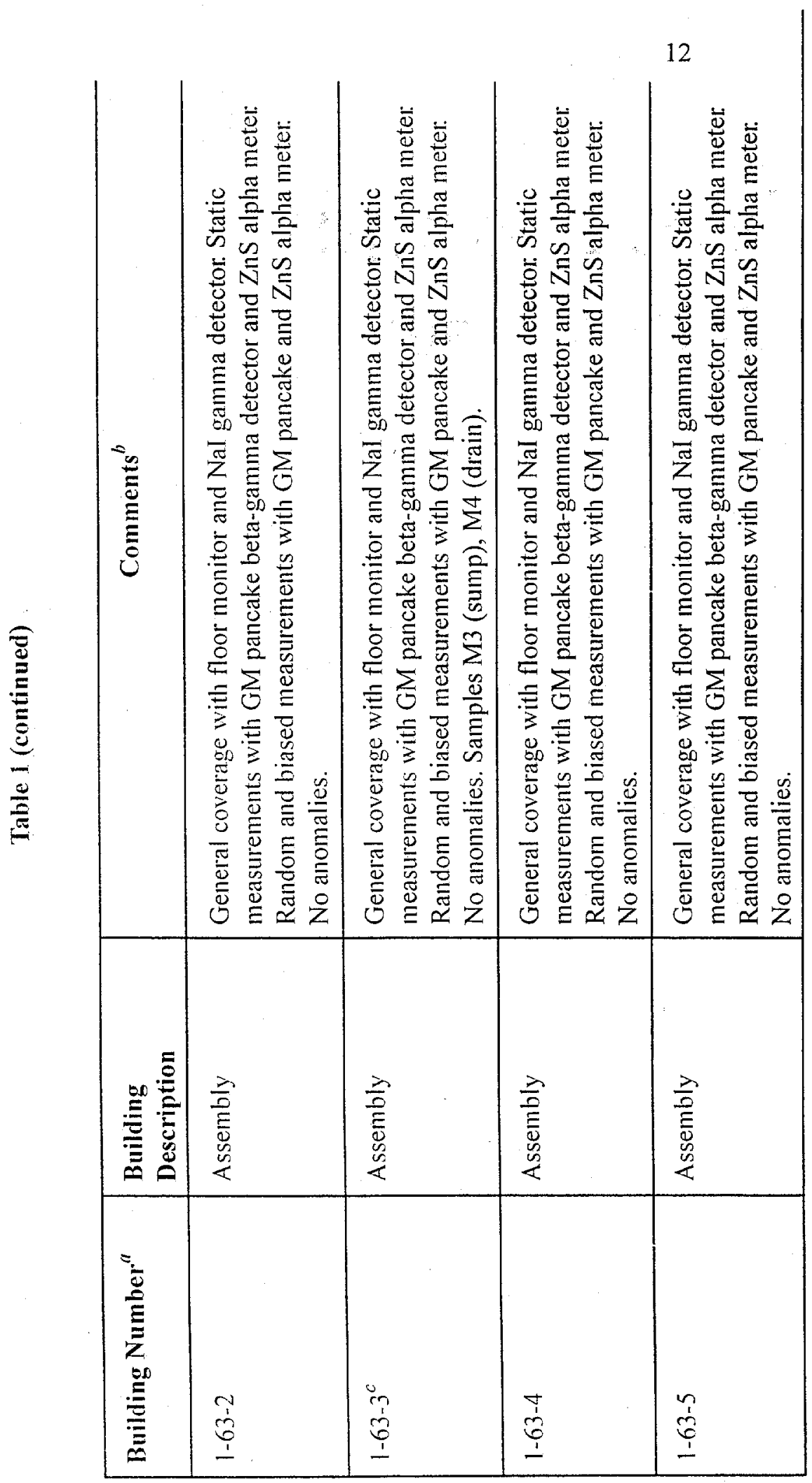


Table 1 (continued)

\begin{tabular}{|c|c|c|}
\hline Building Number & $\begin{array}{l}\text { Building } \\
\text { Description }\end{array}$ & Comments $^{b}$ \\
\hline $1-63-6^{d}$ & Assembly & $\begin{array}{l}\text { General coverage with floor monitor and } \mathrm{NaI} \text { gamma detector: Static } \\
\text { measurements with GM pancake beta-gamma detector and } \mathrm{ZnS} \text { alpha meter. } \\
\text { Random and biased measurements with } \mathrm{GM} \text { pancake and } \mathrm{ZnS} \text { alpha meter. } \\
\text { Radiation sign in entrance. Access to outside entrance of manway blocked. } \\
\text { Spot found near end of manway; } \sim 150,000 \mathrm{dpm} / 100 \mathrm{~cm}^{2} \text { beta, } \\
\sim 290 \mathrm{dpm} / 100 \mathrm{~cm}^{2} \text { alpha. Gamma } 14 \mu \mathrm{R} / \mathrm{h} \text { at spot. Background gamma } \\
9 \mu \mathrm{R} / \mathrm{h} \text {. Samples M2 and T5 laken from manway. Sump and rectangular } \\
\text { drain near assembly area had slightly contaminated sediment. Samples M5 } \\
\text { (sump), M6 (drain). } \\
\text { Complete resurvey of } 1-63-6 \text { : Floor monitor, FIDLER, GM pancake beta- } \\
\text { gamma detector, alpha spot checks with } \mathrm{ZnS} \text { alpha meter. Return air filters } \\
\text { in assembly area generally contaminated. The filter rack housed } 122^{\prime} \times 2^{\prime} \\
\text { filters, generally reading } 20,000 \text { to } 30,000 \mathrm{dpm} / 100 \mathrm{~cm}^{2} \text {. Otherwise, the } \\
\text { assembly area was remarkably clean. Filters appeared relatively new. } \\
\text { Sample M7 (return air filter). }\end{array}$ \\
\hline $1-63-7$ & Assembly & $\begin{array}{l}\text { General coverage with floor monitor and } \mathrm{NaI} \text { gamma detector. Static } \\
\text { measurements with GM pancake beta-gamma detector and } \mathrm{ZnS} \text { alpha meter } \\
\text { Random and biased measurements with } \mathrm{GM} \text { pancake and } \mathrm{ZnS} \text { alpha meter. } \\
\text { No anomalies. Gamma } 10-14 \mu \mathrm{R} / \mathrm{h} \text {. }\end{array}$ \\
\hline $1-64-1$ & Assembly & $\begin{array}{l}\text { General coverage with floor monitor and NaI gamma detector. Static } \\
\text { measurements with GM pancake beta-gamma detector and } \mathrm{ZnS} \text { alpha meter } \\
\text { Random and biased measurements with GM pancake and } \mathrm{ZnS} \text { alpha meter. } \\
\text { No anomalies. }\end{array}$ \\
\hline
\end{tabular}


Table 1 (continued)

\begin{tabular}{|c|c|c|}
\hline Building Number" & $\begin{array}{l}\text { Building } \\
\text { Description }\end{array}$ & Comments $^{b}$ \\
\hline $1-64-2$ & Assembly & $\begin{array}{l}\text { General coverage with floor monitor and } \mathrm{NaI} \text { gamma detector: Static } \\
\text { measurements with GM pancake beta-gamma detector and } \mathrm{ZnS} \text { alpha meter } \\
\text { Random and biased measurements with GM pancake and } \mathrm{ZnS} \text { alpha meter. } \\
\text { No anomalies. }\end{array}$ \\
\hline $1-64-3$ & Assembly & $\begin{array}{l}\text { General coverage with floor monitor and } \mathrm{NaI} \text { gamma detector Static } \\
\text { measurements with GM pancake beta-gamma detector and } \mathrm{ZnS} \text { alpha meter } \\
\text { Random and biased measurements with GM pancake and } \mathrm{ZnS} \text { alpha meter. } \\
\text { No anomalies. }\end{array}$ \\
\hline $1-64-4^{c, d}$ & Assembly & $\begin{array}{l}\text { General coverage with floor monitor and Nal gamma detector: Static } \\
\text { measurements with GM pancake beta-gamma detector and } \mathrm{ZnS} \text { alpha meter } \\
\text { Random and biased measurements with GM pancake and } \mathrm{ZnS} \text { alpha meter. } \\
\text { No anomalies. }\end{array}$ \\
\hline $1-64-5$ & Assembly & $\begin{array}{l}\text { General coverage with floor monitor and } \mathrm{NaI} \text { gamma detector: Static } \\
\text { measurements with GM pancake beta-gamma detector and } \mathrm{ZnS} \text { alpha meter } \\
\text { Random and biased measurements with } \mathrm{GM} \text { pancake and } \mathrm{ZnS} \text { alpha meter. } \\
\text { No anomalies. }\end{array}$ \\
\hline $1-65-1^{d}$ & Storage & $\begin{array}{l}\text { General coverage with floor monitor and } \mathrm{NaI} \text { gamma detector. Static } \\
\text { mcasurements with GM pancake beta-gamma detector and } \mathrm{ZnS} \text { alpha meter } \\
\text { Random and biased measurements with GM pancake and } \mathrm{ZnS} \text { alpha meter. } \\
\text { No anomalies. Gamma } 9 \mu \mathrm{R} / \mathrm{h} \text {. }\end{array}$ \\
\hline $1-65-2$ & Storage & $\begin{array}{l}\text { General coverage with floor monitor and NaI gamma detector. Static } \\
\text { measurements with GM pancake beta-gamma detector and } \mathrm{ZnS} \text { alpha meter } \\
\text { Random and biased measurements with GM pancake and } \mathrm{ZnS} \text { alpha meter. } \\
\text { No anomalies. Gamma } 9 \mu \mathrm{R} / \mathrm{h} \text {. }\end{array}$ \\
\hline
\end{tabular}


Table 1 (continued)

\begin{tabular}{|c|c|c|}
\hline Building Number ${ }^{\prime}$ & $\begin{array}{l}\text { Building } \\
\text { Description }\end{array}$ & Comments $^{b}$ \\
\hline $1-65-3$ & Storagc & $\begin{array}{l}\text { General coverage with floor monitor and Nal gamma detector. Static } \\
\text { measurements with GM pancake beta-gamma detector and } \mathrm{ZnS} \text { alpha meter: } \\
\text { Random and biased measurements with GM pancake and } \mathrm{ZnS} \text { alpha meter: } \\
\text { No anomalies. Gamma } 6 \mu \mathrm{R} / \mathrm{h} \text {. }\end{array}$ \\
\hline $1-65-4$ & Storage & $\begin{array}{l}\text { General coverage with floor monitor and } \mathrm{Nal} \text { gamma detector. Static } \\
\text { measurements with GM pancake beta-gamma detector and } \mathrm{ZnS} \text { alpha meter } \\
\text { Random and biased measurements with } \mathrm{GM} \text { pancake and } \mathrm{ZnS} \text { alpha meter. } \\
\text { No anomalies. Gamma } 7 \mu \mathrm{R} / \mathrm{h} \text {. }\end{array}$ \\
\hline $1-65-5$ & Storage & $\begin{array}{l}\text { General coverage with floor monitor and } \mathrm{Nal} \text { gamma detector. Static } \\
\text { measurements with GM pancake beta-gamma detector and } \mathrm{ZnS} \text { alpha meter } \\
\text { Random and biased measurements with GM pancake and } \mathrm{ZnS} \text { alpha meter: } \\
\text { No anomalies. Gamma } 6 \mu \mathrm{R} / \mathrm{h} \text {. }\end{array}$ \\
\hline $1-65-6$ & Inaccessible & Inaccessible \\
\hline $1-65-7$ & Storage & $\begin{array}{l}\text { General coverage with floor monitor and } \mathrm{NaI} \text { gamma detector. Static } \\
\text { mcasurcments with GM pancake beta-gamma detector and } \mathrm{ZnS} \text { alpha meter } \\
\text { Random and biased measurements with GM pancake and } \mathrm{ZnS} \text { alpha meter. } \\
\text { No anomalies. Gamma } 6 \mu \mathrm{R} / \mathrm{h} \text {. }\end{array}$ \\
\hline $1-66-1$ & Development & $\begin{array}{l}\text { General coverage with floor monitor and Nal gamma detector. Static } \\
\text { measurements with GM pancake beta-gamma detector and } \mathrm{ZnS} \text { alpha meter } \\
\text { Random and biased measurements with GM pancake and } \mathrm{ZnS} \text { alpha meter: } \\
\text { No anomalies. Gamma } 21 \mu \mathrm{R} / \mathrm{h} \text {. }\end{array}$ \\
\hline $1-66-2$ & Development & $\begin{array}{l}\text { General coverage with floor monitor and } \mathrm{NaI} \text { gamma detector. Static } \\
\text { measurements with GM pancake beta-gamma detector and } \mathrm{ZnS} \text { alpha meter } \\
\text { Random and biased measurements with GM pancake and } \mathrm{ZnS} \text { alpha meter. } \\
\text { No anomalies. Gamma } 8 \mu \mathrm{R} / \mathrm{h} \text {. }\end{array}$ \\
\hline
\end{tabular}


Tabie 1 (continued)

\begin{tabular}{|c|c|c|}
\hline Building Number" & $\begin{array}{l}\text { Building } \\
\text { Description }\end{array}$ & Comments ${ }^{b}$ \\
\hline $1-67.1$ & Assembly & $\begin{array}{l}\text { General coverage with floor monitor and } \mathrm{Nal} \text { gamma detector. Static } \\
\text { measurements with GM pancake beta-gamma detector and } \mathrm{ZnS} \text { alpha meter } \\
\text { Random and biased measurements with GM pancake and } \mathrm{ZnS} \text { alpha meter. } \\
\text { No anomalies. }\end{array}$ \\
\hline $1-67-2$ & Assembly & $\begin{array}{l}\text { General coverage with floor monitor and } \mathrm{Nal} \text { gamma detector. Static } \\
\text { measurements with GM pancake beta-gamma detector and } \mathrm{ZnS} \text { alpha meter } \\
\text { Random and biased measurements with GM pancake and } \mathrm{ZnS} \text { alpha meter. } \\
\text { No anomalies. }\end{array}$ \\
\hline $1-67-3$ & Assembly & $\begin{array}{l}\text { General coverage with floor monitor and } \mathrm{NaI} \text { gamma detector. Static } \\
\text { measurements with GM pancake beta-gamma detector and } \mathrm{ZnS} \text { alpha meter } \\
\text { Random and biased measurements with } \mathrm{GM} \text { pancake and } \mathrm{ZnS} \text { alpha meter. } \\
\text { No anomalies. }\end{array}$ \\
\hline $1-77^{d}$ & Shipping/Receiving & $\begin{array}{l}\text { General coverage with floor monitor and NaI gamma detector. Static } \\
\text { measurements with GM pancake beta-gamma detector and } \mathrm{ZnS} \text { alpha meter } \\
\text { Random and biased measurements with GM pancake and } \mathrm{ZnS} \text { alpha meter. } \\
\text { Floor monitor coverage: Perimeter, all cracks and seams. S-pattern } \\
\text { remainder. Beta-gamma pancake corners and walls. No anomalics. }\end{array}$ \\
\hline $1-100-1^{d}$ & X-Ray Facility & $\begin{array}{l}\text { General coverage with floor monitor and NaI gamma detector. Static } \\
\text { measurements with GM pancake beta-gamma detector and } \mathrm{ZnS} \text { alpha meter } \\
\text { Random and biased measurements with GM pancake and } \mathrm{ZnS} \text { alpha meter. } \\
\text { No anomalies. Gamma } 6 \mu \mathrm{R} / \mathrm{h} \text {. }\end{array}$ \\
\hline $1-100-2$ & X-Ray Facility & $\begin{array}{l}\text { General coverage with floor monitor and NaI gamma detector. Static } \\
\text { measurements with GM pancake beta-gamma detector and } \mathrm{ZnS} \text { alpha meter } \\
\text { Random and biased measurcments with GM pancake and } \mathrm{ZnS} \text { alpha meter. } \\
\text { No anomalies. Gamma } 7 \mu \mathrm{R} / \mathrm{h} \text {. }\end{array}$ \\
\hline
\end{tabular}


Table 1 (continued)

\begin{tabular}{|c|c|c|}
\hline Building Number ${ }^{a}$ & $\begin{array}{l}\text { Building } \\
\text { Description }\end{array}$ & Comments $^{b}$ \\
\hline $1-137-4$ & Change House & $\begin{array}{l}\text { General coverage with floor monitor and NaI gamma dctcctor. Static } \\
\text { measurements with GM pancake beta-gamma detector and } \mathrm{ZnS} \text { alpha meter: } \\
\text { Random and biased measurements with GM pancake and } \mathrm{ZnS} \text { alpha meter. } \\
\text { No anomalies. Naturally-occurring radioactive materials in the ceramic tile } \\
\text { floors caused the background to be elevated. Gamma } 6-10 \mu \mathrm{R} / \mathrm{h} \text {. }\end{array}$ \\
\hline $1-148$ & Machining & $\begin{array}{l}\text { General coverage with floor monitor and } \mathrm{NaI} \text { gamma detector Static } \\
\text { measurements with GM pancake beta-gamma detector and } \mathrm{ZnS} \text { alpha meter } \\
\text { Random and biased measurements with GM pancake and } \mathrm{ZnS} \text { alpha meter. } \\
\text { No anomalies. Gamma } 7-9 \mu \mathrm{R} / \mathrm{h} \text {. }\end{array}$ \\
\hline$C$ Yard, $23-53^{C}$ & $\begin{array}{l}\text { Shipping and } \\
\text { Receiving }\end{array}$ & $\begin{array}{l}\text { General coverage with floor monitor and } \mathrm{NaI} \text { gamma detector: Static } \\
\text { measurements with GM pancake beta-gamma detector and } \mathrm{ZnS} \text { alpha meter } \\
\text { Random and biased mcasurements with GM pancake and } \mathrm{ZnS} \text { alpha meter. } \\
\text { No anomalies. Gamma } 7-10 \mu \mathrm{R} / \mathrm{h} \text {. }\end{array}$ \\
\hline C Yard, Igloo 23-1 & Storage & $\begin{array}{l}\text { General coverage with floor monitor and } \mathrm{Nal} \text { gamma detector. Static } \\
\text { measurements with GM pancake beta-gamma detector and } \mathrm{ZnS} \text { alpha meter } \\
\text { Random and biased measurements with GM pancake and } \mathrm{ZnS} \text { alpha meter. } \\
\text { Sample T7. No anomalies. }\end{array}$ \\
\hline C Yard, Igloo 23-2 & Storage & $\begin{array}{l}\text { General coverage with floor monitor and Nal gamma detector. Static } \\
\text { measurements with GM pancake beta-gamma detector and } \mathrm{ZnS} \text { alpha meter } \\
\text { Random and biased measurements with GM pancake and } \mathrm{ZnS} \text { alpha meter. } \\
\text { No anomalies. }\end{array}$ \\
\hline C Yard, Igloo 23-3 & Storage & $\begin{array}{l}\text { General coverage with floor monitor and NaI gamma detector. Static } \\
\text { measurements with GM pancake beta-gamma detector and } \mathrm{ZnS} \text { alpha meter. } \\
\text { Random and biased measurements with GM pancake and } \mathrm{ZnS} \text { alpha meter. } \\
\text { No anomalies. }\end{array}$ \\
\hline
\end{tabular}


Table 1 (continued)

\begin{tabular}{|l|l|l}
\hline Building Number" & $\begin{array}{l}\text { Building } \\
\text { Description }\end{array}$ & \multicolumn{1}{c}{ Comments $^{b}$} \\
\hline Ramps & Transportation & $\begin{array}{l}\text { Ramps were surveyed in the immediate vicinity of the buildings being } \\
\text { surveyed, and in route to survey the various buildings connected by ramps. } \\
\text { No anomalies. }\end{array}$ \\
\hline
\end{tabular}

${ }^{a}$ Line 1 building numbers are coded as follows: $A-B-C$ where: "A" is the IAAAP line number, "B" is an operational function identifier, such as 61 for machining operations, and " $C$ " (if used) is a sequential identifier within an operational grouping.

${ }^{b}$ If no direct gamma reading is given in a building without anomalies, the walkover gamma scan found no radiation distinguishable from instrument background of $5.7 \mu \mathrm{R} / \mathrm{h}$. Gamma readings were taken at 1 meter above the ground for 1 minute.

${ }^{c}$ Air samples were collected from these buildings. See Table 5 .

${ }^{d} \mathrm{PIC}$ measurements were made in these buildings. See Table 4. 
Table 2. Directly measured radiation levels in buildings, Iowa Army Ammunition Plant

\begin{tabular}{|c|c|c|c|}
\hline \multirow[t]{2}{*}{ Location Description } & \multirow{2}{*}{$\begin{array}{l}\text { Measurement } \\
\text { ID }\end{array}$} & Alpha $^{a}$ & Beta-gamma \\
\hline & & \multicolumn{2}{|c|}{$\left(\mathrm{dpm} / 100 \mathrm{~cm}^{2}, 1-\mathrm{minute}\right.$ count $)$} \\
\hline $1-11, \mathrm{SW}$ corner & FP1 & 7 & 1300 \\
\hline $1-11, N W$ corner & FP2 & 14 & 900 \\
\hline $1-11$, center & FP3 & ND & 720 \\
\hline 1-11, NE corner & FP4 & 14 & 780 \\
\hline 1-11, SE corner & FP5 & 14 & 780 \\
\hline 1-11, Bay 1. Crack. Samples T1, M8 & BP1 & 49 & 7500 \\
\hline $\begin{array}{l}\text { 1-11, Bay 1. Concrete seam. Sample } \\
\text { T2 }\end{array}$ & BP2 & 35 & 4400 \\
\hline $\begin{array}{l}\text { 1-11, Bay } 1 . \text { Top of steel grate. Bad } \\
\text { geometry. Sample T3 }\end{array}$ & BP3 & 42 & 31,000 \\
\hline $\begin{array}{l}\text { 1-11, Bay } 1 . \text { No seam. Flat area on } \\
\text { concrete }\end{array}$ & $\mathrm{BP} 4$ & 35 & 3200 \\
\hline 1-11, Bay 1 . Seam at foot of pier & BP5 & 28 & 1300 \\
\hline 1-11, Bay 1 . Seam at edge of pit & BP6 & 7 & 3300 \\
\hline $1-11$, Bay 1 & BP7 & ND & 1400 \\
\hline $\begin{array}{l}\text { 1-11, Sample M1 location before } \\
\text { collection }\end{array}$ & BP8 & & 31,000 \\
\hline $\begin{array}{l}\text { 1-11, Sample M1 location after } \\
\text { collection }\end{array}$ & BP8 & & 14,000 \\
\hline $1-12$, center of Bay AA & FP1 & ND & 540 \\
\hline 1-12, center of Bay BB & $\mathrm{FP} 2$ & 7 & 1400 \\
\hline $1-12$, center of Bay $C C$ & FP3 & ND & 1600 \\
\hline $1-12$, center of Bay DD & FP4 & ND & 780 \\
\hline $1-12$, center of Bay EE & FP5 & ND & 1400 \\
\hline 1-12, center of Bay FF & FP6 & ND & 1700 \\
\hline 1-12, Bay CC. Seam. Samples M9, T6 & $\mathrm{BP} 1$ & 7 & 13,000 \\
\hline
\end{tabular}


20

Table 2 (continued)

\begin{tabular}{|c|c|c|c|}
\hline \multirow[t]{2}{*}{ Location Description } & \multirow{2}{*}{$\begin{array}{l}\text { Measurement } \\
\text { ID }\end{array}$} & Alpha $^{a}$ & Beta-gamma \\
\hline & & \multicolumn{2}{|c|}{$\left(\mathrm{dpm} / 100 \mathrm{~cm}^{2}, 1\right.$-minute count $)$} \\
\hline $1-13$, center of Bay $G$ & FP1 & ND & 720 \\
\hline $1-13$, center of Bay F & FP2 & ND & 720 \\
\hline $1-13$, center of Bay $E$ & FP3 & 7 & 1700 \\
\hline 1-13, center of Bay D & FP4 & 7 & 780 \\
\hline 1-13, center of Bay C & FP5 & ND & 840 \\
\hline $1-13$, center of Bay $A$ & FP6 & ND & 1200 \\
\hline $1-13$, center of Bay $B$ & FP7 & ND & 1500 \\
\hline $1-18$, center of northernmost room & FP1 & 7 & 540 \\
\hline $\begin{array}{l}\text { 1-18, center of next room SW of FP1 } \\
\text { location }\end{array}$ & $\mathrm{FP} 2$ & 7 & 780 \\
\hline $\begin{array}{l}1-18, \text { center of next room SE of FP2 } \\
\text { location }\end{array}$ & FP3 & ND & ND \\
\hline $1-18$, center of hallway & FP4 & ND & 840 \\
\hline $1-18$, center of southernmost room & FP5 & ND & 720 \\
\hline 1-19-1, center & FP1. & 21 & 360 \\
\hline 1-19-2, center & $\mathrm{FP} 1$ & 7 & 180 \\
\hline 1-19-3, center & FPl & 7 & 240 \\
\hline $1-19-4$, center & FP1 & 42 & 60 \\
\hline $1-19-5$ & FP1 & 14 & 660 \\
\hline $1-19-6$, center & FPl & 14 & 360 \\
\hline 1-19-7, center & FP1 & 21 & 660 \\
\hline $1-40$, center of Bay $Q$ & FP1 & 35 & ND \\
\hline $1-40$, center of Bay $S$ & FP2 & 7 & ND \\
\hline $1-40$, center of Bay J & FP3 & 14 & ND \\
\hline $1-40$, center of Bay $\mathrm{H}$ & FP4 & 14 & 720 \\
\hline $1-40$, center of Bay $G$ & FP5 & 35 & 720 \\
\hline
\end{tabular}


21

Table 2 (continued)

\begin{tabular}{|c|c|c|c|}
\hline \multirow{2}{*}{ Location Description } & \multirow{2}{*}{$\begin{array}{c}\text { Measurement } \\
\text { ID }\end{array}$} & Alpha ${ }^{a}$ & Beta-gamma \\
\hline & & \multicolumn{2}{|c|}{$\left(\mathrm{dpm} / 100 \mathrm{~cm}^{2}, 1\right.$-minute count $)$} \\
\hline $1-61$, basement, western side & FP1 & 14 & ND \\
\hline 1-61, basement, eastern side & FP2 & 28 & 1100 \\
\hline $1-61$, basement, center of Bay I & FP3 & 49 & 420 \\
\hline 1-61, upstairs, east side of large room & FP4 & 7 & 600 \\
\hline 1-61, upstairs, west side of large room & FP5 & 21 & 540 \\
\hline 1-61, upstairs, center of Bay R & FP6 & 28 & 360 \\
\hline 1-63-1, entrance & FP1 & 14 & 2000 \\
\hline $\begin{array}{l}\text { 1-63-1, SE side of building. Damp } \\
\text { floor }\end{array}$ & FP2 & ND & 1800 \\
\hline 1-63-1, center of circular room & FP3 & 21 & 660 \\
\hline 1-63-2, entrance & FP1 & 14 & 1100 \\
\hline ]-63-2, SE side of building & FP2 & 28 & 1000 \\
\hline $1-63-2$, center of circular room & FP3 & 28 & 660 \\
\hline 1-63-3, entrance & FP1 & 42 & 660 \\
\hline 1-63-3, SE side of building & FP2 & 28 & $\mathrm{ND}$ \\
\hline 1-63-3, center of circular room & FP3 & 14 & 840 \\
\hline 1-63-4, entrance & FP1 & 7 & 360 \\
\hline 1-63-4, SE side of building & $\mathrm{FP} 2$ & ND & ND \\
\hline 1-63-4, center of circular room & FP3 & 7 & 360 \\
\hline 1-63-5, entrance & FP1 & 21 & 1400 \\
\hline $\begin{array}{l}1-63-5, \text { northern area of building. } \\
\text { Damp vinyl }\end{array}$ & $\mathrm{FP} 2$ & ND & 240 \\
\hline 1-63-5, center of circular room & FP3 & ND & ND \\
\hline 1-63-6, entrance & FP1 & 14 & 720 \\
\hline $1-63-6$, northern area of building & FP2 & ND & 60 \\
\hline $1-63-6$, center of circular room & FP3 & ND & 300 \\
\hline
\end{tabular}


22

Table 2 (continued)

\begin{tabular}{|c|c|c|c|}
\hline \multirow[t]{2}{*}{ Location Description } & \multirow{2}{*}{$\begin{array}{l}\text { Measurement } \\
\text { ID }\end{array}$} & Alpha $^{a}$ & Beta-gamma \\
\hline & & \multicolumn{2}{|c|}{$\left(\mathrm{dpm} / 100 \mathrm{~cm}^{2}, 1\right.$-minute count $)$} \\
\hline $\begin{array}{l}\text { 1-63-6, southern end of manway. } \\
\text { Samples M2, T5 }\end{array}$ & BP1 & 290 & 150,000 \\
\hline $1-63-7$, center of circular room & FP1 & ND & 720 \\
\hline 1-63-7, center & FP2 & ND & 420 \\
\hline $\begin{array}{l}1-63-7, \text { entrance. } \sim 30 \mathrm{ft} . \text { from } 120- \\
\mathrm{mm} \text { DU rounds }\end{array}$ & FP3 & 14 & 1100 \\
\hline 1-64-1, center & FP1 & 7 & 1900 \\
\hline 1-64-2, center & FP1 & 7 & 960 \\
\hline $1-64-3$, center & FP1 & 14 & 180 \\
\hline 1-64-4, center. Door not locked & FP1 & ND & 120 \\
\hline $1-64-5$, center & FP1 & ND & 300 \\
\hline $1-65-1$, center & FP1 & 7 & 480 \\
\hline 1-65-2, center & FP1 & ND & 180 \\
\hline 1-65-3, center & FP1 & 14 & 720 \\
\hline 1-65-4, center & FP1 & 28 & 1000 \\
\hline $1-65-5$, center & FP1 & ND & 180 \\
\hline 1-65-7, center & FP1 & 35 & 540 \\
\hline $\begin{array}{l}\text { 1-66-1, center. } \sim 10 \mathrm{ft} \text {. from DU } \\
\text { ammunition }\end{array}$ & FP1 & 14 & 180 \\
\hline 1-66-2, center & FP1 & 7 & 900 \\
\hline $1-67-1$, center & $\mathrm{FPl}$ & 21 & 120 \\
\hline 1-67-2, center & FP1 & ND & 120 \\
\hline $1-67-3$, center & FPl & 7 & 1100 \\
\hline 1-77, SW corner & FPl & 7 & 900 \\
\hline 1-77, NW corner. Tile floor & $\mathrm{FP} 2$ & ND & ND \\
\hline $1-77$, center & FP3 & 7 & 360 \\
\hline
\end{tabular}


23

Table 2 (continued)

\begin{tabular}{|c|c|c|c|}
\hline \multirow[t]{2}{*}{ Location Description } & \multirow{2}{*}{$\begin{array}{l}\text { Measurement } \\
\text { ID }\end{array}$} & Alpha ${ }^{a}$ & Beta-gamma \\
\hline & & \multicolumn{2}{|c|}{$\left(\mathrm{dpm} / 100 \mathrm{~cm}^{2}, 1-\right.$ minute count $)$} \\
\hline 1-77, NE corner & FP4 & 28 & 720 \\
\hline ]-77, SE corner & FP5 & 7 & 1400 \\
\hline $1-100-1$, center & FP1 & 28 & 540 \\
\hline 1-100-2, center & FPl & 35 & 1200 \\
\hline $1-137-4$, locker room north & FP1 & 14 & $2500^{b}$ \\
\hline 1-137-4, locker room south. Floor tile & FP2 & 14 & $3400^{b}$ \\
\hline 1-137-4, ramp & FP3 & ND & 1300 \\
\hline $1-137-4$, lunch room north & FP4 & ND & $\mathrm{ND}$ \\
\hline 1-137-4, kitchen & FP5 & ND & $3200^{b}$ \\
\hline $\begin{array}{l}1-137-4, \text { hallway from kitchen to } \\
\text { conference room }\end{array}$ & FP6 & 7 & $2200^{b}$ \\
\hline $1-137-4$, lunch room south & FP7 & ND & 1300 \\
\hline $1-148$ & FP1 & ND & 1300 \\
\hline $1-148$ & FP2 & 7 & 1600 \\
\hline $\begin{array}{l}1-01 . \text { Thorium used in welding and } \\
\text { grinding area adjacent to } 1-148\end{array}$ & FP3 & 14 & 1300 \\
\hline $1-148$ & FP4 & ND & $\mathrm{ND}$ \\
\hline $1-148$, center & FP5 & ND & 480 \\
\hline $1-148$ & FP6 & ND & 600 \\
\hline C Yard, 23-53 & FP 1 & 7 & 1200 \\
\hline C Yard, 23-53, Bay A & FP2 & $\mathrm{ND}$ & 780 \\
\hline C Yard, 23-53, Bay B & FP3 & 14 & 1400 \\
\hline C Yard, 23-53 & FP4 & 7 & 1500 \\
\hline C Yard, 23-53 & FP5 & 14 & 480 \\
\hline C Yard, Igloo Cl, center & FP1 & 42 & 2500 \\
\hline C Yard, Igloo C2, center & $\mathrm{FP} 1$ & ND & 1900 \\
\hline
\end{tabular}


Table 2 (continued)

\begin{tabular}{|c|c|c|c|}
\hline \multirow[t]{2}{*}{ Location Description } & \multirow{2}{*}{$\begin{array}{c}\text { Measurement } \\
\text { ID }\end{array}$} & Alpha $^{a}$ & Beta-gamma \\
\hline & & \multicolumn{2}{|c|}{ (dpm/100 $\mathrm{cm}^{2}, 1-$ minute count) } \\
\hline C Yard, Igloo C3, center & FP1 & ND & 1000 \\
\hline
\end{tabular}

Table 3. Smear data from buildings at Iowa Army Ammunition Plant

\begin{tabular}{|c|c|c|c|c|c|}
\hline \multirow{3}{*}{$\begin{array}{l}\text { Smear } \\
\text { number }\end{array}$} & \multirow[t]{3}{*}{ Location } & \multicolumn{2}{|c|}{$\begin{array}{c}\text { Directly measured radiation } \\
\text { levels }\end{array}$} & \multicolumn{2}{|c|}{ Removable radioactivity } \\
\hline & & Alpha & Beta-gamma & Alpha & Beta-gamma \\
\hline & & \multicolumn{2}{|c|}{$\left(\mathrm{dpm} / 100 \mathrm{~cm}^{2}\right)$} & \multicolumn{2}{|c|}{$\left(\mathrm{dpm} / 100 \mathrm{~cm}^{2}\right)$} \\
\hline $\mathrm{T} 1$ & 1-11, Bay 1, crack & 49 & 7500 & ND & 17 \\
\hline $\mathrm{T} 2$ & $\begin{array}{l}\text { 1-11, Bay } 1, \\
\text { concrete seam }\end{array}$ & 35 & 4400 & ND & ND \\
\hline $\mathrm{T} 3$ & $\begin{array}{l}1-11, \text { Bay } 1, \text { steel } \\
\text { grate }\end{array}$ & 42 & 31,000 & ND & 17 \\
\hline $\mathrm{T} 4$ & 1-61, Bay R, pan & 1000 & 30,000 & 630 & 2500 \\
\hline T5 & 1-63-6, manway & 290 & 150,000 & 21 & ND \\
\hline 16 & $\begin{array}{l}\text { 1-12, Bay CC, } \\
\text { crack }\end{array}$ & 7 & 13,000 & ND & 29 \\
\hline $\mathrm{T} 7$ & $\begin{array}{l}\text { Yard C, Igloo 23-1, } \\
\text { floor }\end{array}$ & NM & NM & ND & ND \\
\hline
\end{tabular}

ND $=$ Not detected.

$\mathrm{NM}=$ Not measured. 
Table 4. Summary of pressurized ionization chamber (PIC) measurements at the Iowa Army Ammunition Plant

\begin{tabular}{lc}
\hline \multicolumn{1}{c}{ Building location } & $\begin{array}{c}\text { Direct exposure measurements } \\
(\mu \mathrm{R} / \mathrm{h})\end{array}$ \\
\hline $1-11$ (Center of building) & 8 \\
$1-11$ (Center of area with elevated radiation levels) & 8 \\
$1-61$ & 7 \\
$1-63-6$ & 9 \\
$1-64-4$ & 9 \\
$1-65-1$ & 9 \\
$1-77$ & 8 \\
$1-100-1$ & 7 \\
\hline
\end{tabular}

Table 5. Air particulate sample data from buildings at Iowa Army Ammunition Plant ${ }^{a}$

\begin{tabular}{|c|c|c|c|c|c|c|}
\hline $\begin{array}{l}\text { Sample } \\
\text { number }\end{array}$ & $\begin{array}{l}\text { Building } \\
\text { location }\end{array}$ & Start date & $\begin{array}{l}\text { Start } \\
\text { time }\end{array}$ & Total time & $\begin{array}{c}\text { Gross } \\
\text { alpha } \\
(\mu \mathrm{Ci} / \mathrm{cc})^{b}\end{array}$ & $\begin{array}{c}\text { Percent of } \\
\mathrm{U}-238 \\
\mathrm{DCG}^{c}\end{array}$ \\
\hline $\mathrm{Zl}$ & $1-11$ & $6-12-00$ & 3:30 p.m. & $16 \mathrm{~h} 40 \mathrm{~min}$ & $3.8 \mathrm{E}-15$ & 4 \\
\hline $\mathrm{Z} 2$ & $\begin{array}{l}1-63-3, \text { center } \\
\text { of press room }\end{array}$ & $6-13-00$ & 4:50 p.m. & $16 \mathrm{~h} 17 \mathrm{~min}$ & $5.3 \mathrm{E}-15$ & 5 \\
\hline $\mathrm{Z3}$ & $1-64-4$ & $6-14-00$ & 3:55 p.m. & $16 \mathrm{~h} 55 \mathrm{~min}$ & $1.1 \mathrm{E}-14$ & 11 \\
\hline Z4 & $1-40$, Bay G & $6-15-00$ & 3:20 p.m. & $18 \mathrm{~h}$ & $4.5 \mathrm{E}-14$ & 45 \\
\hline Z5 & $1-19-3$ & $6-19-00$ & 4:07 p.m. & $15 \mathrm{~h} 34 \mathrm{~min}$ & $2.0 \mathrm{E}-14$ & 20 \\
\hline Z6 & Yard C, 23-53 & $6-20-00$ & 9:05 a.m. & $6 \mathrm{~h} 30 \mathrm{~min}$ & $N D$ & $\ldots$ \\
\hline
\end{tabular}

The pump ID number was 349002 AS. Starting and ending flow rates were $20 \mathrm{~L} / \mathrm{min}$. Sampling height was approximately $1.5 \mathrm{~m}$.

${ }^{b}$ Background ambient air radioactivity has not been subtracted.

${ }^{c}$ The non-occupational Derived Concentration Guide (DCG) is $1.0 \mathrm{E}-13 \mu \mathrm{Ci} / \mathrm{cc}$. 
Table 6. Concentrations of radionuclides in samples from Line 1, Iowa Army Ammunition Plant, Middletown, Iowa

\begin{tabular}{|c|c|c|c|c|c|c|c|c|}
\hline \multirow{2}{*}{$\begin{array}{l}\text { Sample } \\
\text { ID }^{\prime \prime}\end{array}$} & \multirow[t]{2}{*}{ Building } & \multirow{2}{*}{$\begin{array}{l}\text { Location } \\
\text { description }\end{array}$} & \multicolumn{6}{|c|}{ Radionuclide concentrations $(\mathrm{pCi} / \mathrm{g})^{h \cdot c}$} \\
\hline & & & ${ }^{2.5} \mathrm{U}$ & ${ }^{2{ }^{2} \mathrm{U}}$ & ${ }^{26} \mathrm{Ra}$ & ${ }^{137} \mathrm{Cs}$ & ${ }^{232} \mathrm{Th}$ & ${ }^{40} \mathrm{~K}$ \\
\hline $\mathrm{S1}$ & $1-11$ & $\begin{array}{l}\text { Soil outside } \\
\text { NW comer }\end{array}$ & $N D^{\prime \prime}$ & $3.9 \pm 0.7$ & $0.7 \pm 0.3$ & $0.7 \pm 0.2$ & $0.8 \pm 0.2$ & $13 \pm 4$ \\
\hline M1 & $|-1|$ & $\begin{array}{l}\text { Floor crack, } \\
\text { south side of } \\
\text { building }\end{array}$ & $400 \pm 50$ & $19,000 \pm 1000$ & ND & $N D$ & $N D$ & $N D$ \\
\hline M2 & $1-63-6$ & Manway & $570 \pm 100$ & $39,000 \pm 3000$ & $N D$ & $N D$ & $N D$ & $N D$ \\
\hline M3 & $1-63-3$ & Sump & $N D$ & $0.5 \pm 0.1$ & $0.3 \pm 0.1$ & $N D$ & $0.5 \pm 0.1$ & $7 \pm 3$ \\
\hline M4 & $1-63-3$ & Floor drain & $N D$ & $1.0 \pm 1$ & $0.5 \pm 0.2$ & $N D$ & $0.3+0.2$ & $6 \pm 3$ \\
\hline M5 & $1-63-6$ & Sump & $0.6 \pm 0.3$ & $10 \pm 4$ & $1.9 \perp 0.5$ & $N D$ & $1.9 \pm 0.3$ & $6.4 \pm 1.4$ \\
\hline M6 & $1-63-6$ & Floor drain & $1.3 \pm 0.8$ & $86 \pm 2$ & $1.2 \pm 0.6$ & $N D$ & $0.5 \pm 0.2$ & $8 \pm 5$ \\
\hline M7 & $1-63-6$ & Air filter & $36 \pm 10$ & $2600 \pm 200$ & $3 \pm 4$ & $N D$ & $N D$ & $N D$ \\
\hline M8 & $1-11$ & $\begin{array}{l}\text { NW corner of } \\
\text { building }\end{array}$ & $2.4 \pm 0.2$ & $130 \pm 30$ & $0.4 \pm 0.1$ & ND & $0.5 \pm 0.1$ & $14 \pm 2$ \\
\hline M9 & $\begin{array}{l}1-12, \\
\text { Bay CC }\end{array}$ & $\begin{array}{l}\text { Center floor } \\
\text { crack }\end{array}$ & $7.0 \pm 0.7$ & $180 \pm 20$ & $0.5 \pm 0.2$ & $0.2 \pm 0.2$ & $0.7 \pm 0.2$ & $12 \pm 2$ \\
\hline $\mathrm{T} 4$ & $\begin{array}{l}1-61 \\
\text { Bay R } \\
\end{array}$ & Plastic pan & $37 \pm 12$ & $2700 \pm 300$ & $N D$ & $N D$ & $N D$ & $N D$ \\
\hline $\begin{array}{l}\text { Typical } a \\
\text { radionuc }\end{array}$ & $\begin{array}{l}\text { iori MDA } \\
\text { : }\end{array}$ & & 0.5 & 0.7 & 0.3 & 0.04 & 0.4 & 0.5 \\
\hline
\end{tabular}

${ }^{a}$ Debris samples $(\mathrm{MH})$ and smear $(\mathrm{T} \#)$ were taken from locations with elevated beta-gamma radiation levels. Sample locations are shown on Figs. 4 and 5.

${ }^{b}$ Indicated counting error is at the $95 \%$ confidence level $( \pm 2 \sigma)$.

${ }^{c} A$ typical cleanup guideline for total uranium (U-238 $\left.+\mathrm{U}-235+\mathrm{U}-234\right)$ is $60 \mathrm{pCi} / \mathrm{g}$.

${ }^{\prime} N D=$ Not detected above the MDA for the radionuclide. Am-241 was not identified in any sample at an MDA of $0.02 \mathrm{pCi} / \mathrm{g}$. 


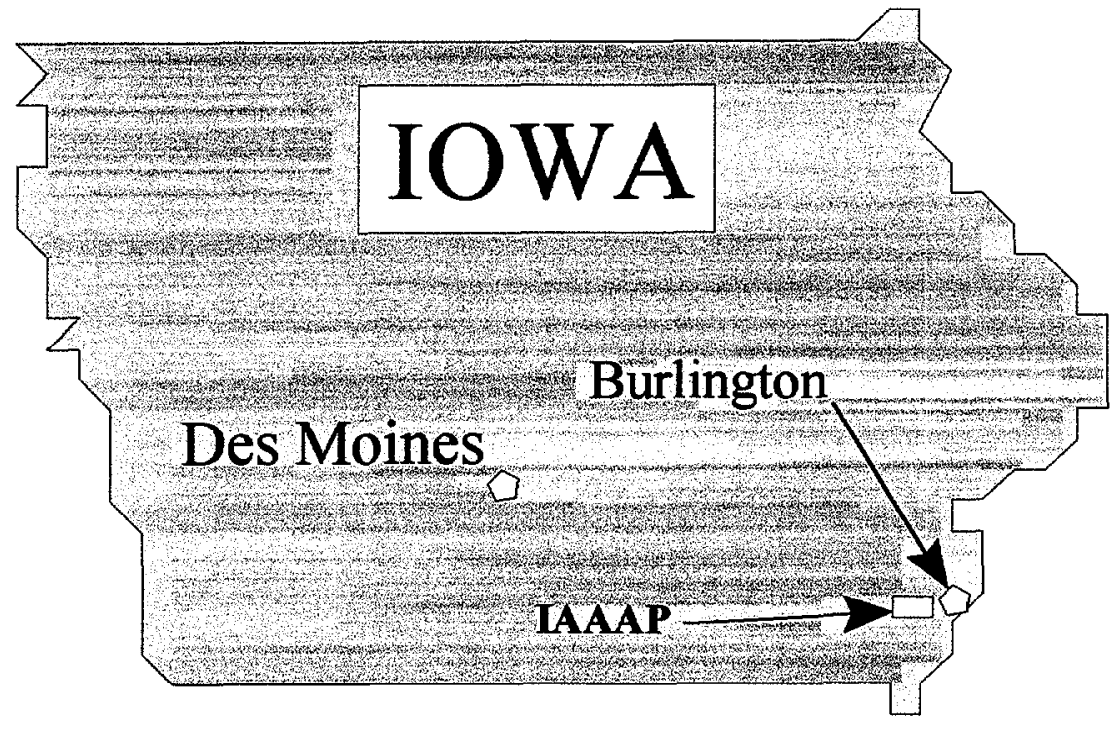

Fig. 1. Map of Iowa showing the general location of the Iowa Army Ammunition Plant (IAAAP), Middletown, Iowa. 


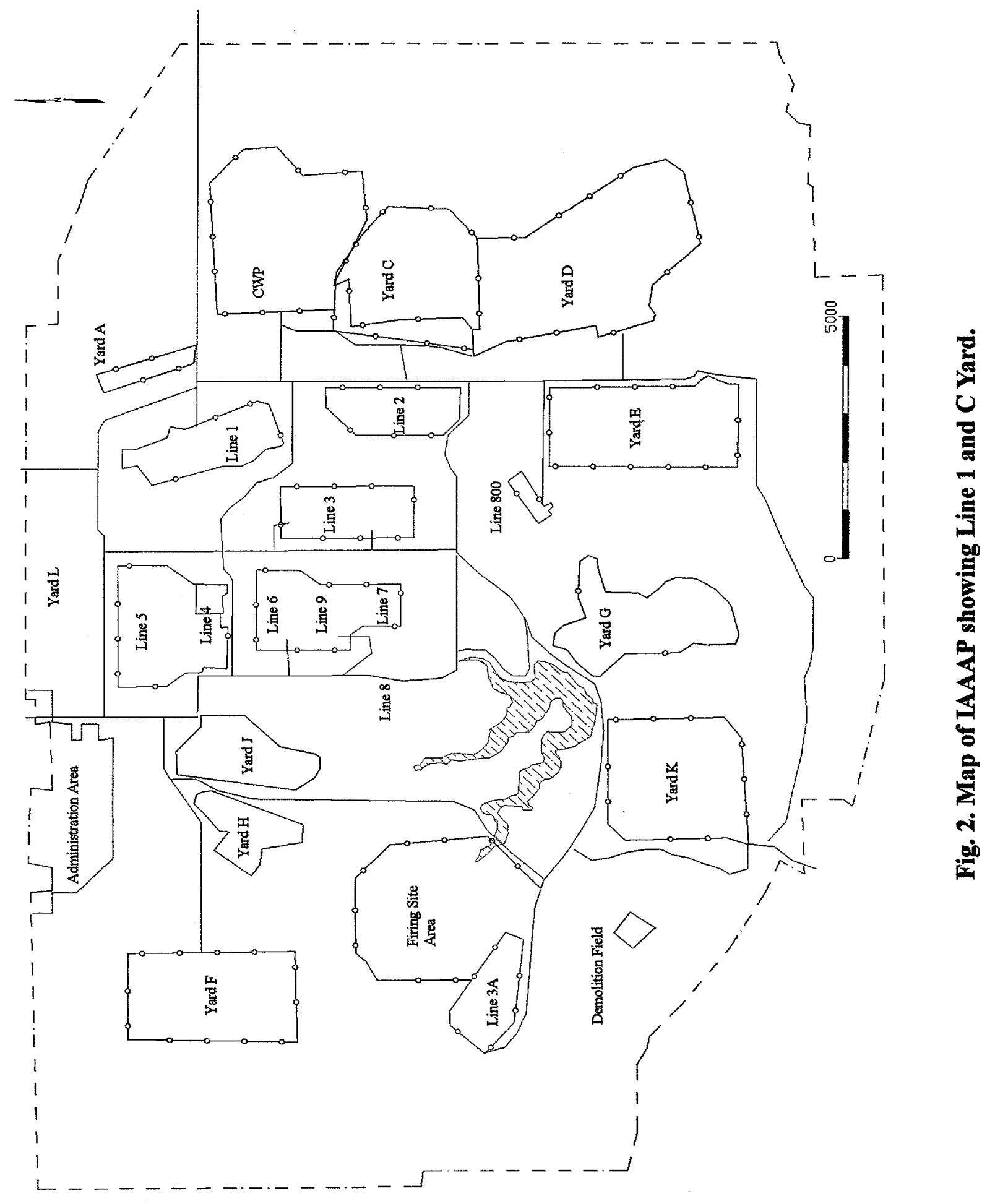




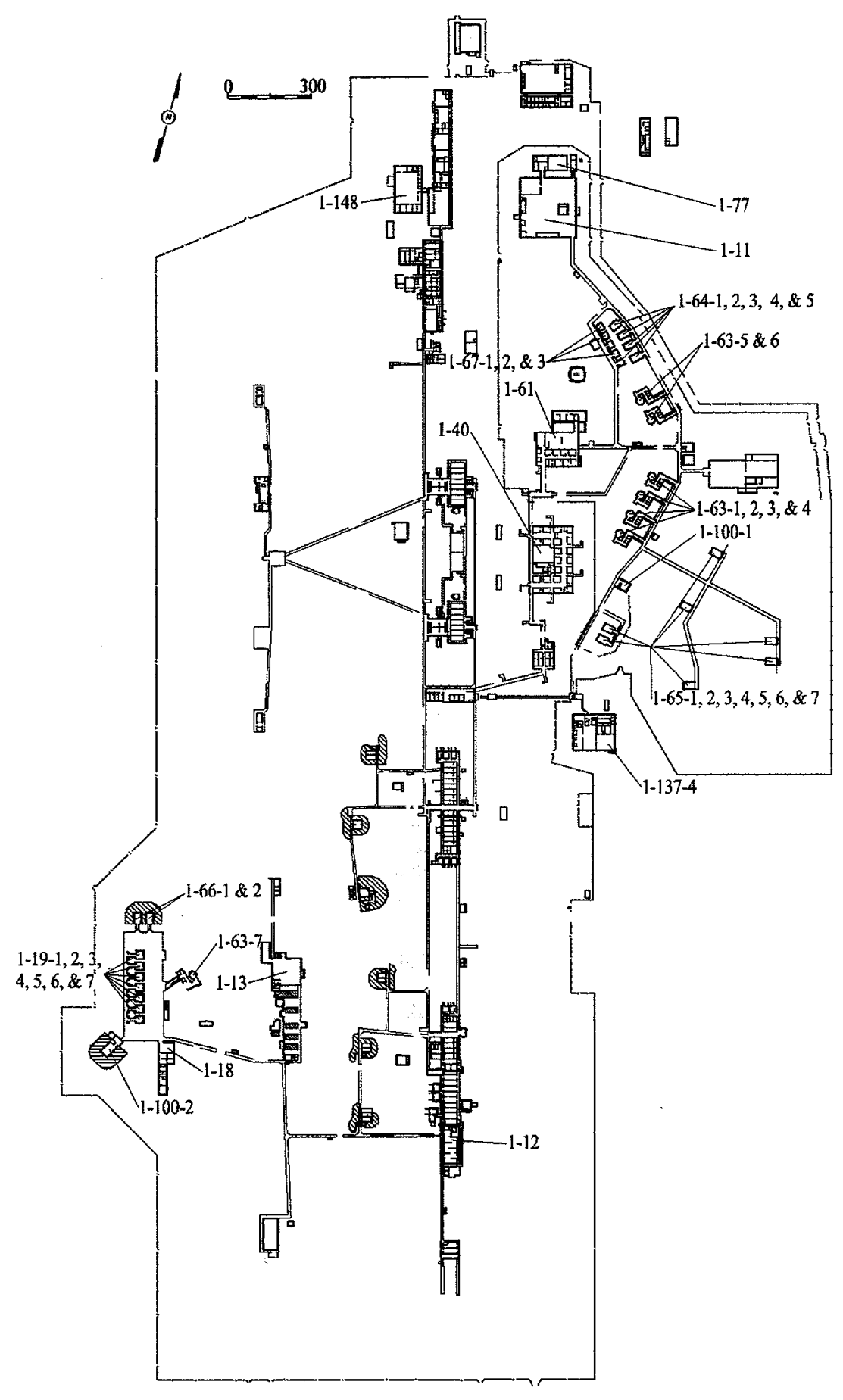

Fig. 3. Diagram showing surveyed buildings at Line 1, IAAAP. 

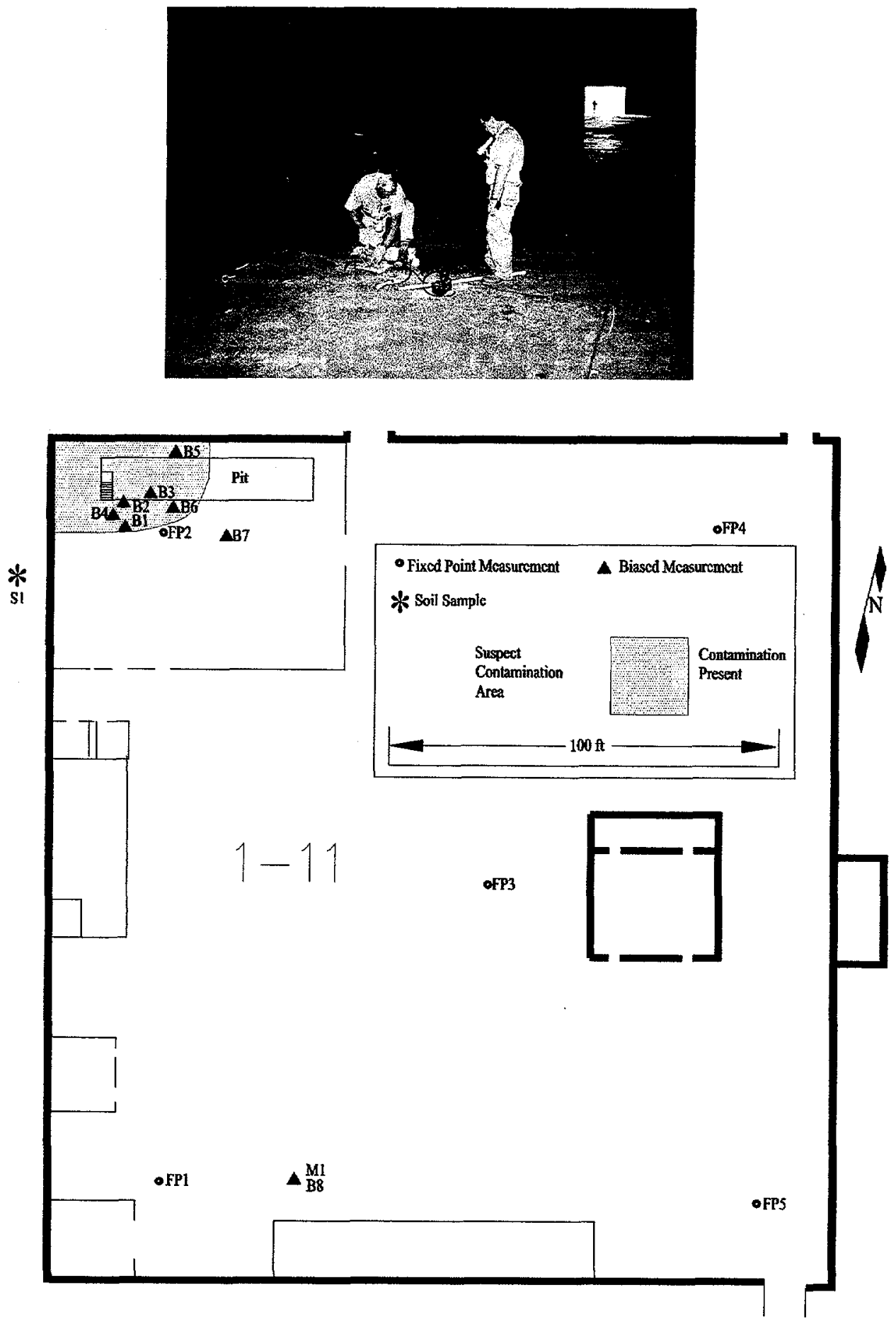

Fig. 4. Diagram of Building 1-11 showing results of radiation survey and a view of sample collection. 


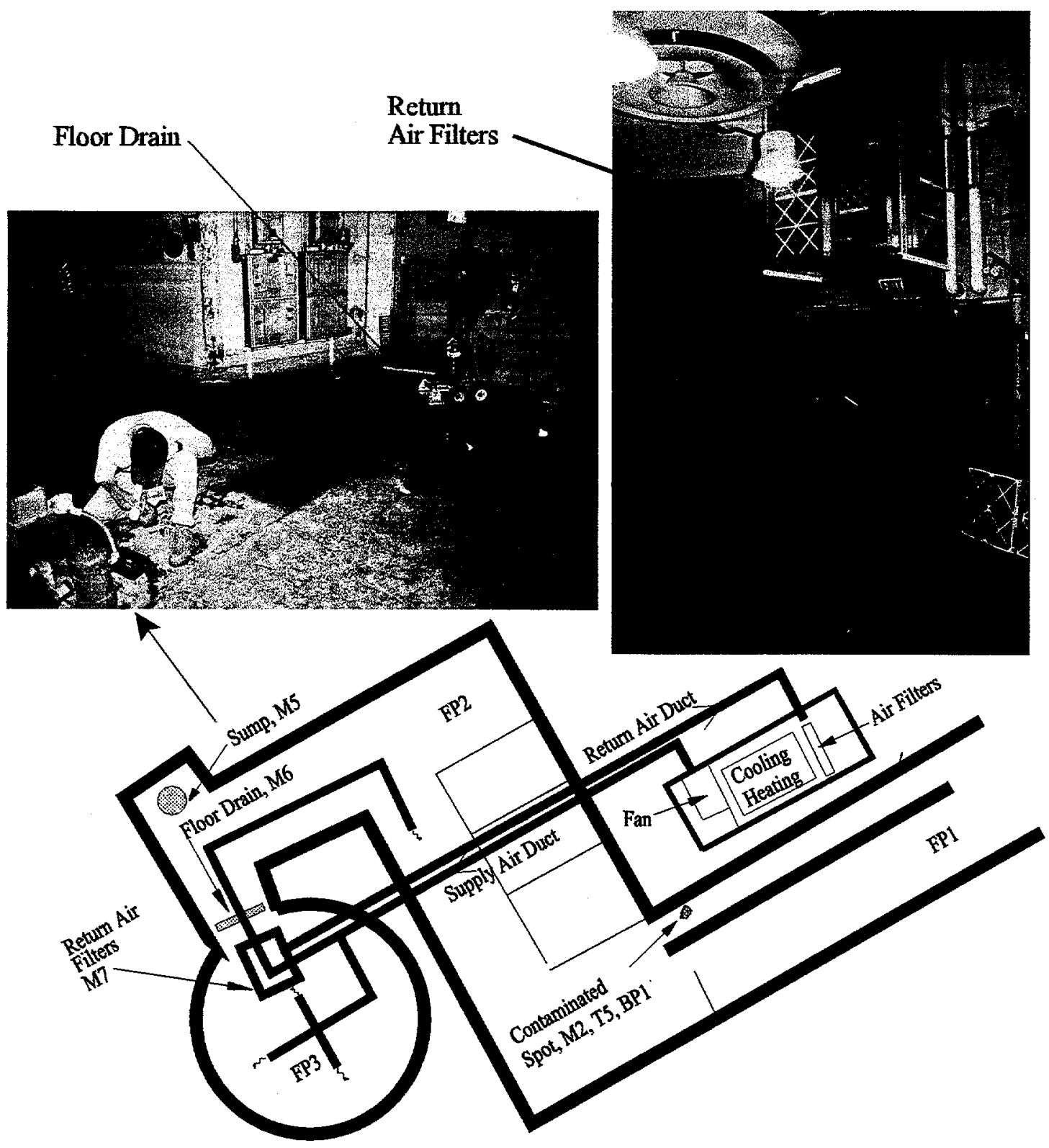

Fig. 5. Diagram of Building 1-63-6 showing results of radiation survey and views of return air filters and sample collection. 


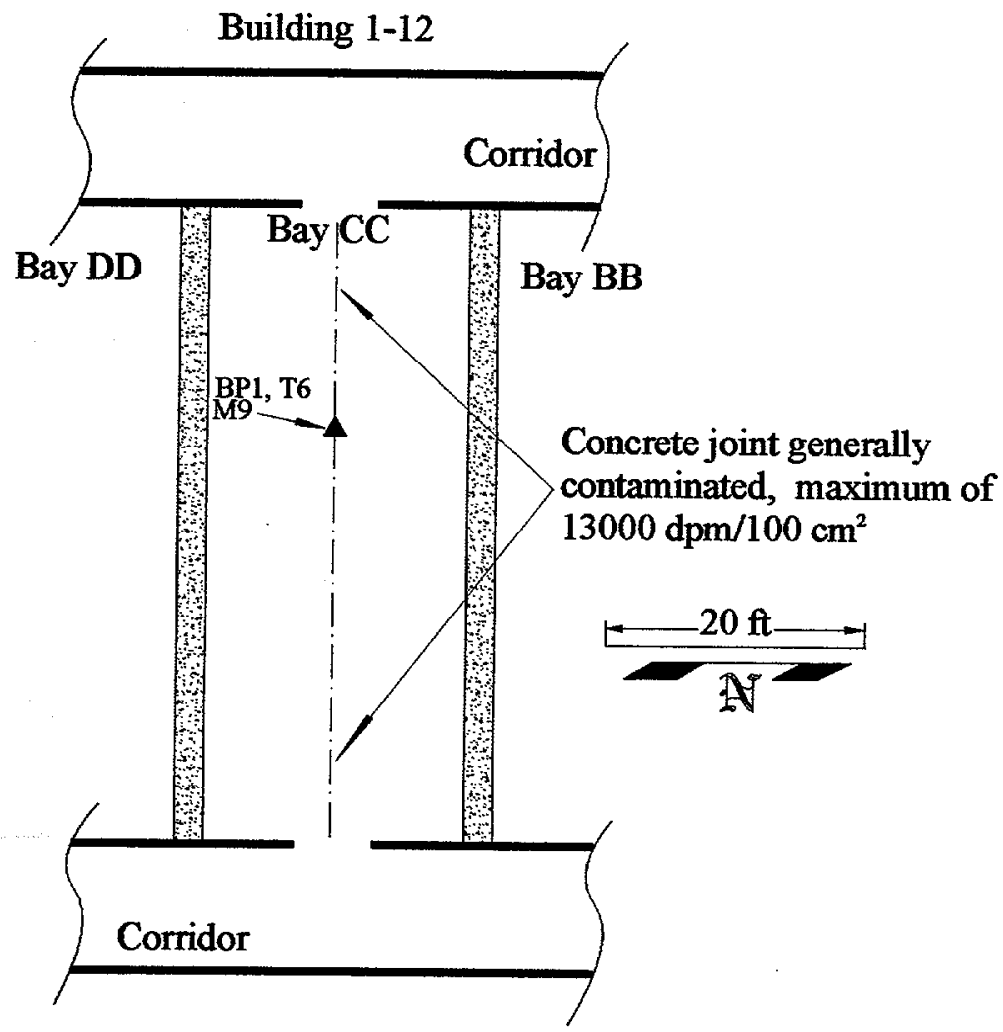

Fig. 6. Diagram of Building 1-12 showing results of radiation survey. 


\section{DISTRIBUTION}

I. R. L. Coleman

2. P. Y. Lu

3-13. M. E. Murray

14. R. E. Rodriguez

15-20. MAD Records Center

21. Central Research Library

22. Laboratory Records $-\mathrm{RC}$

23-34. D. Bourne, Environmental Restoration Division, U.S. Department of Energy, P.O. Box 5400, Albuquerque, NM $87185-5400$

35-36. W. A. Williams, Office of Environmental Restoration, Cloverleaf Bldg. (EM-421), U.S. Department of Energy, 19901 Germantown Road, Germantown, MD 20874-1290

37-38. Office of Scientific and Technical Information, U.S. Department of Energy, P.O. Box 62, Oak Ridge, TN 37831-0062 
